\title{
Geochemistry of the Phlegraean Fields (Italy) proximal sources for major Mediterranean tephras: implications for the dispersal of Plinian \& co- ignimbritic components of explosive eruptions
}

\author{
Emma L. Tomlinson ${ }^{1 *}$, Ilenia Arienzo ${ }^{2}$, Lucia Civetta ${ }^{2,3}$, Sabine Wulf ${ }^{4}$, Victoria C. \\ Smith $^{5}$, Mark Hardiman ${ }^{6}$, Christine S. Lane ${ }^{5}$, Antonio Carandente ${ }^{2}$, Giovanni \\ Orsi $^{2}$, Mauro Rosi ${ }^{7}$, Wolfgang Müller ${ }^{1}$, Matthew F. Thirlwall ${ }^{1}$ and Martin A. \\ Menzies $^{1}$ \\ ${ }^{1}$ Department of Earth Sciences, Royal Holloway University of London, Egham, \\ U.K. \\ ${ }^{2}$ Istituto Nazionale di Geofisica e Vulcanologia, sezione di Napoli-Osservatorio \\ Vesuviano, Napoli, Italy. \\ ${ }^{3}$ Dipartimento di Scienze Fisiche, Università di Napoli Federico II, Napoli, Italy. \\ ${ }^{4}$ GFZ German Research Centre for Geosciences, Section 5.2 - Climate \\ Dynamics and Landscape Evolution, Potsdam, Germany \\ ${ }^{5}$ Research Laboratory for Archaeology and the History of Art, University of \\ Oxford, Oxford, United Kingdom \\ ${ }^{6}$ Centre of Quaternary Research, Department of Geography, Royal Holloway \\ University of London, Egham, Surrey, United Kingdom. \\ ${ }^{7}$ Dipartimento di Scienze della Terra, Università di Pisa, Pisa, Italy.
}

\section{ABSTRACT}

Volcanic activity at Phlegraean Fields, Italy, produced several major marker tephras over a 50 ka period. The caldera forming eruptions of the Campanian Ignimbrite $(\mathrm{Cl})$ and Neapolitan Yellow Tuff (NYT) are of particular importance for tephrostratigraphy in Europe. Other key eruptions from this source include the Pomici Principali (PP) and the Tufi Biancastri eruptions. We combine analyses of fresh glasses from proximal locations (i.e., juvenile clasts in proximal flow and fall deposits) with data for key tephra layers from Lago Grande di Monticchio, $120 \mathrm{~km}$ to the east. The micron-beam major (EMPA) and trace (LA-ICP-MS) element glass dataset allows us to: (a) Distinguish between tephra units produced from the Phlegraean Fields before and during the $\mathrm{Cl}$ eruption (Cl-series), and before and during the NYT and PP eruptions (NYT-series/PP); (b) Discriminate between the $\mathrm{Cl}$ and the geochemically similar Pre-Cl pyroclastic deposits; (c) Separate the NYT from Pre-NYT tephra units, although both major and trace elements do show significant overlap. The complex compositional overlap between Pre-NYT tephras may present a problem for tephra correlations in the 14-39 ka time window and may have resulted in incorrect proximal-distal and distal-distal correlations. The diagnostic chemical criteria detailed herein permits more accurate matching of distal tephras with their proximal equivalents and hence will improve chronostratigraphy of distal settings and give insight into tephra dispersal. We show that the dispersal of PP tephra was more limited than previously thought. The surge/fall (Lower Member) and subsequent pyroclastic density current (Upper Member) phases of the NYT eruption can be recognised 
in distal settings. Both the NYT Lower and Upper Members are found in distal localities to the east of the Phlegraean Fields, however the Lower Member is found in the absence of the Upper Member in locations to the far north of Phlegraean Fields. Chemical compositions of the Plinian and ignimbrite phases of the $\mathrm{Cl}$ eruption overlap extensively, but can be distinguished on a plot of $\mathrm{Zr}-\mathrm{Th}$.

\section{Key Words: Tephrostratigraphy, LA-ICP-MS, Campi Flegrei, Campanian Ignimbrite, Neapolitan Yellow Tuff, Lago Grande di Monticchio}

\section{INTRODUCTION}

Tephra layers deposited during large explosive volcanic eruptions form important isochronous marker beds in the stratigraphic record, allowing correlation between archaeological, terrestrial, marine and ice records (tephrostratigraphy). In addition, if the tephra can be correlated to a source and age of the eruption is well established, distal ash layers can be used as age markers within the stratigraphic record (tephrochronology). Furthermore, a reliable correlation between proximal and distal facies of an eruption deposit allows the eruption volume and tephra dispersal pattern to be reconstructed. Knowledge of these two parameters is important in volcanic hazards assessments and zoning of the territory in relation to the expected hazards. This is critical for active, restless and densely populated volcanoes such as the Phlegraean Fields resurgent caldera (Orsi et al., 1996, 1999a, b, 2004, 2009; Costa et al., 2009; Selva et al., 2012).

70

71 Tephra produced during the two most recent caldera forming eruptions at

72 Phlegraean Fields (Fisher et al., 1993; Orsi et al., 1996), the Campanian 73 Ignimbrite $\left(\mathrm{Cl}, 39.28 \pm 0.11{ }^{40} \mathrm{Ar} /{ }^{39} \mathrm{Ar}\right.$ ka; De Vivo et al., 2001) and the Neapolitan 74 Yellow Tuff (NYT, $14.9 \pm 0.4{ }^{40} \mathrm{Ar} /{ }^{39} \mathrm{Ar}$ ka; Deino et al., 2004), provide important 75 stratigraphic markers in European Quaternary deposits (e.g. Schmidt et al., 2002; 76 Fedele et al., 2003; Pyle et al., 2006; Giaccio et al., 2008). The Cl was the most 77 explosive eruption of the Campanian Volcanic Zone (CVZ) and the largest known 78 volcanic event in the Mediterranean region in the last 200 ka (Barberi et al., 79 1978). The $\mathrm{Cl}$ has been correlated with distal occurrences of the $\mathrm{Y}-5$ tephra in 80 the eastern Mediterranean, central and eastern Europe and Russia (e.g. Keller et 81 al., 1978; Thunell et al., 1979; Paterne et al., 1988; Vezzoli, 1991; Pyle et al., 82 2006). The $\mathrm{Cl}$ is linked with layer TM-18 (36.77 varve ka BP) in the Lago Grande 83 di Monticchio sediment core (Wulf et al., 2004). Some 25 ka later, activity in the 84 Phlegraean Fields caldera produced the NYT. The NYT has been correlated with 85 the 13.84-14.88 cal ka BP ${ }^{1} \mathrm{C}-2$ tephra layer in the Tyrrhenian and Adriatic Seas 86 (Paterne et al., 1988; Calanchi et al., 1998; Siani et al., 2004; Bourne et al.,

\footnotetext{
${ }^{1}$ All radiocarbon ages presented here (cal ka BP) have been calibrated using the IntCal09 or Marine09 internationally accepted calibration curves (Reimer et al., 2009 ) at $2 \sigma$. Year 0 is 1950 AD. Please see references for uncalibrated radiocarbon determinations.
} 
2010) and with TM-8 (14.12 varve ka BP) in the Lago Grande di Monticchio core

88 (Wulf et al., 2004; 2008). The smaller Pomici Principali (PP, also known as

89 Agnano Pomici Principali) eruption dated at 11.92-12.26 cal ka BP (Smith et al.,

90 2011) has been correlated with TM-7b (12.18 varve ka BP) in the Lago Grande di

91 Monticchio core (Wulf et al., 2004; 2008) and has also been described in the

92 Adriatic Sea (Paterne et al., 1988; Calanchi et al., 1998; Siani et al., 2004;

93 Bourne et al., 2010) and several lake settings (Magne et al., 2006; Sulpizio et al.,

94 2009; Lane et al., 2011).

95

96

97

98

99

100

101

102

103

104

105

106

107

108

109

110

111

112

113

114

115

116

117

118

119

120

121

122

123

124

125

126

127

128

129

130

131
Diagnostic glass chemistries for each eruption are essential in order to verify the use of PP, NYT and $\mathrm{Cl}$ in tephrostratigraphy and tephrochronology. However, both the $\mathrm{Cl}$ and NYT display chemical zoning in proximal deposits (Orsi et al., 1992; 1995; Civetta et al., 1997; Pappalardo et al., 2002a). In addition, a number of smaller eruptions at Phlegraean Fields also form stratigraphic markers in Quaternary deposits across the Mediterranean. These smaller eruptions were fed by trachyte and phonolite magmas with similar chemistries to the $\mathrm{Cl}$ and NYT products. At least twelve Pre-Campanian Ignimbrite (Pre-Cl) units are recognised at the Trefola Quarry (Orsi et al., 1996) spanning 59-39 ka (Pappalardo et al., 1999). Several of these eruptions produced quite thick $(>10 \mathrm{~m})$ proximal pyroclastic fall and density current deposits generated by high-energy explosive eruptions from vents outside the caldera (Orsi et al., 1996). At least 20 distinct tephra layers have been recognised for the same time window in the medialdistal Lago Grande di Monticchio core (Wulf et al., 2007).

Between the $\mathrm{Cl}$ and NYT eruptions, numerous surges and minor fall deposits were generated from intra-caldera phreatomagmatic eruptions (Orsi et al., 1996). ${ }^{40} \mathrm{Ar} /{ }^{39} \mathrm{Ar}$ dated eruptions range in age from $30.3 \mathrm{ka}(\mathrm{VRa})$ to $14.6 \mathrm{ka}$ (PRe) (Pappalardo et al., 1999). These Pre-NYT units, deposited over a period of $25 \mathrm{ka}$, are known collectively as Tufi Biancastri (Rittmann, 1950). Several distal tephras are found in this time window. At least 10 Pre-NYT tephra layers are recorded in the Lago Grande di Monticchio core, with TM-9 and TM-15 being the most prominent (Wulf et al., 2004, 2007, 2008). TM-9 is linked to GM1. In distal settings GM1 comprises two tephra layers closely spaced in time and is dated at 14.2-16.2 cal ka BP (Siani et al., 2004; Aufgebauer et al., 2012). TM-15 is correlated with the 30-31 cal ka BP $\mathrm{Y} 3$, described in marine and terrestrial settings across the central Mediterranean (Zanchetta et al., 2008).

The aims of this study using Electron Microprobe Analysis (EMPA) and Laser Ablation Inductively Coupled Plasma Mass Spectrometry (LA-ICP-MS) of single glass shards, are: 1) to define the diagnostic major and trace element geochemistry of the PP, NYT and $\mathrm{Cl}$ glasses and to investigate their compositional heterogeneity; 2) to use these diagnostic geochemisties to investigate the dispersal of the PP, NYT and Cl tephra; and 3) to investigate the geochemistry of pyroclastic-fall and flow deposits that predate the $\mathrm{Cl}$ and the NYT eruptions. Defining diagnostic chemistries of these Pre-Cl and Pre-NYT 
units would not only allow them to be distinguished from the $\mathrm{Cl}$ and NYT events, but also allows them to be used as stratigraphic markers.

\section{GEOLOGICAL OUTLINE}

The Phlegraean Fields lie in the Campanian Plain along the Tyrrhenian margin of the southern Apennines and is part of the Quaternary potassic province. The Phlegraean Fields comprises a $13 \mathrm{~km}$ wide nested caldera in the Gulf of Naples, formed mainly as a consequence of the eruption of the Cl and NYT (Orsi et al., 1996). The caldera margins are poorly exposed and on the south lie beneath the Bay of Pozzuoli. The Phlegraean Fields has been active since at least $60 \mathrm{ka}$ (Pappalardo et al., 1999) and many of the eruptions from the Phlegraean Fields had large Plinian columns $(>40 \mathrm{~km}$ ) that deposited widespread fall and flow units. Numerous eruptions have taken place since the NYT eruption during three epochs of activity (Di Vito et al., 1999) from vents located either along the faults bordering the caldera or along the extensional faults bordering the La Starza resurgent block (Orsi et al., 1996). The most recent eruption produced the Monte Nuovo tuff cone in 1538 AD (D'Oriano et al., 2005).

PP was a sub-Plinian to Plinian eruption, which dispersed pumice and ash mainly towards the east (Lirer et al., 2001). PP was dominantly phreatomagmatic and deposited alternating pumice/ash fall units and pyroclastic density currents (Smith et al., 2011), which show a progressive increase in magma discharge rate, as indicated by an increase in grain size and proportion of lithic fragments with stratigraphic height (Lirer et al., 2001). PP magmas are tephri-phonolitic to phonolitic (D'Antonio et al., 2007; Arienzo et al., 2010; Smith et al., 2011).

The NYT is the largest known trachytic phreato-Plinian eruption, extruding $>40$ $\mathrm{km}^{3}$ dense rock equivalent (DRE) of latitic-to-trachytic magma, (Orsi et al., 1992, 1995; Wohletz et al., 1995). Deposits of the NYT are chemically zoned and were produced from three distinct magma batches, which are not related by fractional crystallisation (Orsi et al., 1995). The NYT sequence is divided into a Lower Member (LM) and an Upper Member (UM). The LM comprises a surge deposit (LM1) produced from a central vent, overlain by an alternating sequence of phreato-Plinian surge and Plinian fall deposits (LM2-LM13) all erupted from a central vent (Orsi et al., 1995; Orsi et al., 1992; Wohletz et al., 1995). The UM was erupted from multiple vents and deposited as pyroclastic density currents following column collapse (Orsi et al., 1995; Orsi et al., 1992; Wohletz et al., 1999). The poorly evolved latitic-trachitic magma dominated the end of the eruption (Orsi et al., 1992; 1995; Wohletz et al., 1995) and is not recorded in the precursor eruptions (Pabst et al., 2008).

The $\mathrm{Cl}$ erupted at least $300 \mathrm{~km}^{3}$ DRE (Fedele et al., 2003) of magma during two major phases. The first phase was Plinian and produced a column that reached a maximum height of $44 \mathrm{~km}$ and deposited pumice and ash predominantly to the south-east (Rosi et al., 1999). The second phase accompanied caldera collapse 
and was characterised by highly inflated pyroclastic density currents that flowed over the sea and crossed mountain ridges in excess of a thousand meters (Fisher et al., 1993; Ort et al., 2003). Breccias were emplaced during the course of the eruption (Fedele et al., 2008). The superposition of the variable and chemically distinct pyroclastic density currents is documented in a core drilled in the northern part of the city of Naples (Pappalardo et al., 2002a). On the basis of the reconstruction of the $\mathrm{Cl}$ chemical stratigraphy from the drill core, we will refer to the three recognised pyroclastic density currents units as the lower, intermediate and upper flow units. The explosive phases that generated these units were fed by the most differentiated phonolitic magma, the compositionally intermediate and the least differentiated trachytic magmas, respectively (Civetta et al., 1997; Pappalardo et al., 2002a).

189

190

191

192

193

194

195

196

197

198

199

200

201

202

203

204

205

206

207

208

209

210

211

212

213

214

215

216

217

218

219

220

221

222

223

The $\mathrm{Cl}$ magma chamber was compositionally zoned and is generally considered to have comprised two distinct magmas (trachytic and phonolitic), which mixed during the eruption (Fedele et al., 2008; Arienzo et al., 2009; Civetta et al., 1997; Pappalardo et al., 2002a). There is some debate as to the relationships between the trachytic and phonolitic layers. Some authors have suggested that the phonolitic cap was generated by undercooling and rapid crystallisation of the trachyte magma and later assimilation (Bohrson et al., 2006; Fowler et al., 2007; Pappalardo et al., 2008). Fedele et al., (1008) suggest that the Cl magmas in the Breccia Museo formation are related by fractional crystallisation. However, the least and most evolved $\mathrm{Cl}$ end-member magmas have different $\mathrm{Sr}$ - and $\mathrm{Nd}$ isotope signatures suggesting that they evolved separately (Arienzo et al., 2009). The least evolved component is seen only at the end of the $\mathrm{Cl}$ eruption (Arienzo et al., 2009; Pabst et al., 2008). This suggests late recharge of the $\mathrm{Cl}$ chamber by trachytic magma that crystallised ca. 6 ka before eruption (Arienzo et al., 2011).

The chemical heterogeneity of the $\mathrm{Cl}$ and NYT is believed to result mostly from recharge of the shallow reservoir by arrivals of less differentiated magmas and mixing (Orsi et al., 1995; Pabst et al., 2008; Arienzo et al., 2009). In contrast, the Pre-Cl and Pre-NYT fall units each have a more restricted compositional range (Pabst et al., 2008). On the basis of geochemical and isotopic data, Pabst et al. (2008) argue that: 1) the Pre- $\mathrm{Cl}$ eruptions represent distinct magma batches in multiple chambers, the last of which may have provided a mixing end-member for the $\mathrm{Cl}$, later influxed by less differentiated, less radiogenic magma; and 2) the Pre-NYT magmas evolved independently from the preceding $\mathrm{Cl}$ magmatic system. The Pre-Cl, Cl and Pre-NYT, NYT are decoupled both geochemically and isotopically and show evidence of increasing crustal contamination through time since 60 ka (Di Renzo et al., 2011, D’Antonio et al., 2007; Pappalardo e al., 2002b; Pabst et al., 2008; Tonarini et al., 2004).

\section{SAMPLES}

\subsection{Proximal Samples}


The ash/tephra (<2 mm) component of Plinian and co-ignimbrite clouds can be dispersed by tropospheric and stratospheric systems and deposited in distal localities, therefore in our proximal study we have primarily sampled thick fall and flow deposits. Samples from the $\mathrm{Cl}$ and NYT and several major Pre-Cl and PreNYT eruptions were taken from well-studied outcrops from various locations in the Campanian Region (Fig. 1, Table 1). Numerous smaller eruptions recorded in the stratigraphy at Trefola quarry and elsewhere are described in detail in Pabst et al. (2008) and Pappalardo et al. (2002b).

The $\mathrm{Cl}$ and NYT were both sampled at four separate localities; the Pre-Cl was sampled at Trefola (TL) quarry and the Pre-NYT at Trefola and Verdolino (VR) quarries and at Ponti Rossi (PR). The PP samples come from Via Pigna. Eruptions were sampled at various levels, except for thin deposits $(<2 \mathrm{~m})$ where only one representative sample was collected. Details of the eruptions sampled and sample localities are given in Table 1. Thirty pumice/scoria clasts were sampled from each level. Clasts were crushed and clean fragments from the interiors of each individual clast was picked and mounted in 'Stuers EpoFix' epoxy resin.

\subsection{Lago Grande di Monticchio samples}

We compare the proximal samples to distal tephra preserved within the Lago Grande di Monticchio core, discussed in detail in Narcisi, (1996) and Wulf et al. (2004, 2008). This lake provides an ideal distal archive for Campanian tephra due to its location $120 \mathrm{~km}$ east of the Phlegraean Fields (Fig. 1) on the dispersal axis of most eruptions (e.g. Santacroce et al., 2003). The Lago Grande di Monticchio core spans $135 \mathrm{ka}$ and preserves $>340$ distinct tephra layers, of which $>300$ are thought to originate from the Campanian region (Wulf et al., 2004). The laminated sediments of the lake provide a high-precision varve age record (Wulf et al., 2008). Incremental counting error on Lago Grande di Monticchio varve ages is estimated to be $5-10 \%$ (Brandt et al., 1999; Brauer et al., 2000; Wulf et al., 2008). We have determined the major and trace element compositions of prominent layers from this lake that were previously correlated to the PP (TM-7b), NYT (TM-8) and Cl (TM-18-top and TM-18-base) and with key Campanian tephra in the Pre-NYT (TM-9, TM-15) time window. Pumice and glass shards from the Lago Grande di Monticchio tephra layers were picked and mounted in 'Stuers EpoFix' epoxy resin for analysis.

\section{ANALYTICAL METHODS}

\subsection{Electron Micro-Probe Analysis}

Major element compositions were determined using Jeol8600 electron microprobe, equipped with 4 wavelength dispersive spectrometers and SamX software, at the Research Laboratory for Archaeology and the History of Art, University of Oxford. An accelerating voltage of $15 \mathrm{kV}$, low beam current $(6 \mathrm{nA})$, 
and defocused $(10 \mu \mathrm{m})$ beam were used to minimize Na migration. Count times were $30 \mathrm{~s}$, except for $\mathrm{Na}(10 \mathrm{~s}$ ) and $\mathrm{P}$ and $\mathrm{Cl}$ (each $60 \mathrm{~s}$ ). The instrument was calibrated using a suite of appropriate mineral standards. The calibration was verified using a range of secondary glass standards from the Max Planck Institute, Leipzig, Germany. Secondary glass (MPI-DING suite; Jochum et al., 2006) and mineral (Smithsonian Institute; Jarosewich, 2002) standards were analysed between and within runs. The PAP absorption correction method was used. Three replicate analyses were made on each sample and analyses with totals of $<95 \%$ were discarded. Sample totals are normalised to $100 \mathrm{wt} \%$ in all plots and tables. Accuracies of analyses of the MPI-DING glasses are $<5 \%$ for concentrations $>0.8 \mathrm{wt} \%$; concentrations $<0.2 \mathrm{wt} \%$ are more qualitative. Analytical precision is $<10 \%$ relative standard deviation (\%RSD) for analytes with concentrations $>0.8 \mathrm{wt} \%$. Error bars on plots show 2 s.d. of replicate analyses of StHs6/80-G and ATHO-G.

\subsection{Laser Ablation Inductively Coupled Plasma Mass Spectrometry}

LA-ICP-MS analyses of proximal tephra samples were performed using an Agilent 7500ce coupled to a Resonetics $193 \mathrm{~nm}$ ArF excimer laser-ablation system (RESOlution M-50 prototype) with a two-volume ablation cell (Müller et al., 2009) at the Department of Earth Sciences, Royal Holloway University of London. We used 57,34 and $25 \mu \mathrm{m}$ laser spots, depending on the size of the area available for analysis in individual samples. The repetition rate was $5 \mathrm{~Hz}$ and the count time was $40 \mathrm{~s}$ (200 pulses) on the sample and $40 \mathrm{~s}$ on the gas blank (background). Concentrations were calibrated using NIST612 with ${ }^{29} \mathrm{Si}$ as the internal standard. Data reduction was performed manually using Microsoft Excel allowing removal of portions of the signal compromised by the occurrence of microcrysts, full details of the analytical and data reduction methods are given in Tomlinson et al. (2010). Accuracies of analyses of ATHO-G and StHs6/80-G MPI-DING glass analyses are typically $<5 \%$. Reproducibility of ATHO-G analyses is $<5$ RSD\% for all trace elements except for V (ATHO-G) and Gd (StHs6/80-G), which are close to LOD. Relative standard errors (\%RSE) for sample tephra analyses are typically $<2 \% R S E$ for $\mathrm{V}, \mathrm{Rb}, \mathrm{Y}, \mathrm{Zr}, \mathrm{Nb}, \mathrm{La}, \mathrm{Ce}, \mathrm{Pr}$. $\mathrm{Th}, \mathrm{U}$; and $<5 \%$ for $\mathrm{Ti}, \mathrm{Sr}, \mathrm{Ba}, \mathrm{Nd}, \mathrm{Sm}, \mathrm{Eu}, \mathrm{Gd},<\mathrm{Dy}, \mathrm{Er}, \mathrm{Yb}$, Lu and Ta. Full errors (standard deviations and standard errors for individual sample analyses) are given in the supplementary information. For consistency with EMPA error reporting, error bars on plots show 2 s.d. of replicate analyses of StHs6/80-G and ATHO-G.

\section{RESULTS}

Representative major and trace element compositions of proximal pumice glasses are given in Tables 2 and 3 and of distal Lago Grande di Monticchio glass shards in Table 4. The full dataset is available as supplementary data. In this section we will highlight aspects of the chemistry that allow us to distinguish between the eruptive units, thus revealing the chemical features that can be used 
in proximal-distal correlations. Diagnostic ratios are summarised in Table 5. Eruptive units are described in order of increasing age consistent with the order of occurrence of tephra with increasing depth in sedimentary records.

\subsection{PP}

The PP glasses are phonolitic (56.58-58.71 $\left.\mathrm{wt} \% \mathrm{SiO}_{2}\right)$ and extend into the tephriphonolite field (Fig. 2) with increasing stratigraphic height. There is a negative relationship between $\mathrm{SiO}_{2}$ and $\mathrm{CaO}, \mathrm{MgO}, \mathrm{FeO}$ and $\mathrm{TiO}_{2} ; \mathrm{K}_{2} \mathrm{O}(7.9-9.3$ wt\%) slightly increases with increasing $\mathrm{SiO}_{2}$, while $\mathrm{Al}_{2} \mathrm{O}_{3}(18.5-19.5$ wt\%), $\mathrm{MnO}(0.1-$ $0.2 \mathrm{wt} \%$ ) and $\mathrm{Na}_{2} \mathrm{O}$ (3.3-3.9 wt\%) remain approximately constant (Fig. 3a-f). PP glasses have a low degree of evolution $\left(\mathrm{Zr} / \mathrm{Sr}=0.27-0.36\right.$ and $\mathrm{Eu} / \mathrm{Eu}^{*} \mathrm{~N}=0.65-$ $0.94)$ and are characterised by relatively low Th concentrations $(20-29 \mathrm{ppm})$ with constant ratios of HFSE to Th $(\mathrm{Nb} / \mathrm{Th}=1.75 \pm 0.15 ; \mathrm{Zr} / \mathrm{Th}=10.5 \pm 0.5 ; \mathrm{Y} / \mathrm{Th}=$ $1.0 \pm 0.1 ; \mathrm{Ta} / \mathrm{Th}=0.08 \pm 0.01)$ and high $\mathrm{V}$ concentrations (94-132 ppm) (Fig. 4af).

PP glasses overlap extensively with the low $\mathrm{SiO}_{2}$ component of the NYT- LM and -UM glasses (section 4.2), but have lower $\mathrm{MgO}$ (and to a lesser extent $\mathrm{FeO}$ ) for a given $\mathrm{SiO}_{2}$ content (Fig. 3a-f). Therefore, the PP and NYT units can be distinguished using major element compostions.

\subsection{NYT-series (NYT, Pre-NYT)}

Pre-NYT and NYT glasses show a negative relationship between $\mathrm{SiO}_{2}$ and $\mathrm{CaO}$, $\mathrm{MgO}, \mathrm{FeO}$ and $\mathrm{TiO}_{2} ; \mathrm{K}_{2} \mathrm{O}$ and $\mathrm{Na}_{2} \mathrm{O}$ show an inflection at $\sim 60 \mathrm{wt} \% \mathrm{SiO}_{2}$ with $\mathrm{Na}_{2} \mathrm{O}$ increasing and $\mathrm{K}_{2} \mathrm{O}$ decreasing at higher $\mathrm{SiO}_{2} ; \mathrm{Al}_{2} \mathrm{O}_{3}$ stays approximately constant (Fig. 3a-f). Chlorine is positively correlated with $\mathrm{Na}_{2} \mathrm{O}$. The Pre-NYT units form clusters at the most and least evolved ends of the array, while the NYT itself spans the whole compositional range. The NYT-series glasses have constant ratios of HFSE to Th: Nb/Th $=1.7 \pm 0.1 ; \mathrm{Zr} / \mathrm{Th}=10.9 \pm 0.6 ; \mathrm{Ta} / \mathrm{Th}=$ $0.08 \pm 0.01$. They show low degrees of evolution (Fig. $4 \mathrm{~b}$ ): $\mathrm{Eu} \mathrm{Eu}^{*}{ }_{\mathrm{N}}=0.3-1.0$, the largest being observed in the Pre-NYT unit TLo; $\mathrm{Zr} / \mathrm{Sr}=0.2-7$ in most NYT-series units and 30-59 in TLo (Fig. 5f). The NYT-series has high V concentrations (20170 ppm, Fig. 5e).

\subsubsection{NYT}

Glasses from analysed NYT-LM units (LM1, LM3, LM13) form two clusters separated by a distinct compositional gap (LM3 and LM13 both have $>3.8 \mathrm{wt} \%$ $\mathrm{CaO},<59 \mathrm{wt} \% \mathrm{SiO}_{2} ; \mathrm{LM} 1$ has $<2.6 \mathrm{wt} \% \mathrm{CaO}$ and $\left.>61 \mathrm{wt} \% \mathrm{SiO}_{2}\right)$. The $\mathrm{LM} 1$ glass is a trachyte (Fig. 2), and not strongly evolved $(\mathrm{Sr} / \mathrm{Zr}=0.4-1.8)$ with weak anomalies relating to feldspar fractionation $\left(\mathrm{Eu} / \mathrm{Eu}^{*}{ }_{\mathrm{N}}=0.6-0.9 ; \mathrm{Sr} / \mathrm{Pr}_{\mathrm{N}}=0.8-1.2\right)$. The LM3 and LM13 glasses are phono-trachytes (Fig. 2) and also only weakly evolved $(\mathrm{Sr} / \mathrm{Zr}=0.3-0.4)$ but with higher incompatible element concentrations and larger $\mathrm{Eu}$ and $\mathrm{Sr}$ anomalies $\left(\mathrm{Eu} / \mathrm{Eu}^{*}{ }_{\mathrm{N}}=0.6-0.8 ; \mathrm{Sr} / \mathrm{Pr}_{\mathrm{N}}=0.7-0.9\right)$ than LM1. 
362

363

364

365

366

367

368

369

370

371

372

373

374

375

376

377

378

379

380

381

382

383

384

385

386

387

388

389

390

391

392

393

394

395

396

397

398

399

400

401

402

403

404

405

406

407

These two clusters represent magma 1 and magma 2 described by Orsi (1995). Glass shards of less differentiated composition (latite to trachyte), corresponding to magma 3 of Orsi et al. (1995), are not seen in this study.

Glasses from the units of the UM straddle the phonolite-trachyte boundary and span a wide compositional range between the two LM clusters and extend to less evolved compositions, with $56.0-62.1 \mathrm{wt} \% \mathrm{SiO}_{2}$ and $2.0-5.1 \mathrm{wt} \% \mathrm{CaO}$ (Fig. 3) and $\mathrm{Zr} / \mathrm{Sr}=0.2-7.3$.

In summary, NYT glasses are characterised by the following compositional features:

1. Straddle the phono-trachyte boundary at $56.0-62.1 \mathrm{wt} \% \mathrm{SiO}_{2}$.

2. The analysed LM units are bimodal with a trachytic component $(<2.6 \mathrm{wt} \%$ $\mathrm{CaO}$ and $>61 \mathrm{wt} \% \mathrm{SiO}_{2}$ ) and a phono-trachytic component (>3.8 wt\% $\mathrm{CaO},<59 \mathrm{wt} \% \mathrm{SiO}_{2}$ ).

3. The UM forms a continuum which overlaps with the two LM clusters and extends to less differentiated compositions.

\subsubsection{Pre-NYT}

The Pre-NYT units are collectively known as Tufi Biancastri (Rittmann, 1950), however they represent the products of several eruptions. Here we have analysed four Pre-NYT units, these are (youngest to oldest): PRa $(16.1 \pm 0.2$ ${ }^{40} \mathrm{Ar} /{ }^{39} \mathrm{Ar} \mathrm{ka}$; Pappalardo et al., 1999), VRb, VRa $\left(30.3 \pm 0.2{ }^{40} \mathrm{Ar} /{ }^{39} \mathrm{Ar} \mathrm{ka}\right.$; Pappalardo et al., 1999) and TLo. The PRa, VRb and TLo units have restricted compositional ranges, while the VRa forms two clusters.

Glasses from the Pre-NYT PRa are trachytic (Fig. 2) with $62.4 \pm 0.5 \mathrm{wt} \% \mathrm{SiO}_{2}$, and $2.2 \pm 0.3 \mathrm{wt} \% \mathrm{CaO}$. They are moderately enriched in trace elements $(\mathrm{Sr} / \mathrm{Zr}=$ $1.3 \pm 0.4 ; \mathrm{Eu} / \mathrm{Eu}^{*}{ }_{N}=0.68 \pm 0.07 ; \mathrm{Sr} / \mathrm{Pr}_{\mathrm{N}}=0.23 \pm 0.09$ ) and overlap with the trachytic NYT, LM1 glasses.

Glasses from Pre-NYT VRb are trachytic (Fig. 2) with $62.2 \pm 0.4$ wt\% $\mathrm{SiO}_{2}$ and $2.2 \pm 0.2 \mathrm{wt} \% \mathrm{CaO}$. In terms of trace elements, the VRb glasses are moderately enriched ( $\mathrm{Sr} / \mathrm{Zr}=1.7 \pm 1.2$; Fig. 5$)$ and largely overlap with the PRa glasses, but show a slightly wider compositional range extending to slightly higher HFSE concentrations and slightly larger feldspar related anomalies (Eu/Eu* $N=0.6 \pm$ 0.1 ; $\mathrm{Sr} / \mathrm{PrN}=0.20 \pm 0.14$; Fig. 4). Glasses from unit VRb also overlap with the trachytic NYT-LM1.

Glasses from the Pre-NYT VRa are bimodal (Fig. 2-5). One population is trachytic $\left(62.3 \pm 0.4 \mathrm{wt} \% \mathrm{SiO}_{2}, 2.2 \pm 0.1 \mathrm{wt} \% \mathrm{CaO}\right)$ with moderate enrichment levels and Eu and $\mathrm{Sr}$ anomalies $\left(\mathrm{Sr} / \mathrm{Zr}=1.4 \pm 1.0 ; \mathrm{Eu} / \mathrm{Eu}^{*}{ }_{\mathrm{N}}=0.70 \pm 0.15 ; \mathrm{Sr} / \mathrm{Pr}_{\mathrm{N}}\right.$ $=0.25 \pm 0.14)$. This cluster overlaps with trachytic NYT-LM1. The second population is phono-trachytic $\left(58.0 \pm 0.5 \mathrm{wt} \% \mathrm{SiO}_{2}, 4.0 \pm 0.3 \mathrm{wt} \% \mathrm{CaO}\right)$, is weakly enriched $(\mathrm{Sr} / \mathrm{Zr}=0.34 \pm 0.02$; Fig. 5$)$ and has small feldspar related 
408

409

410

411

412

413

414

415

416

417

418

419

420

421

422

423

424

425

426

427

428

429

430

431

432

433

434

435

436

437

438

439

440

441

442

443

444

445

446

447

448

449

450

451

452

453

anomalies $\left(E u / E u_{N}^{*}=0.81 \pm 0.04 ; \mathrm{Sr} / \operatorname{Pr}_{N}=0.86 \pm 0.04\right.$; Fig 4). This cluster overlaps with the phono-trachytic NYT-LM (LM3 + LM13), but extends to slightly higher $\mathrm{FeO}$ and $\mathrm{MgO}$ for a given $\mathrm{SiO}_{2}$ concentration, and has slightly lower $\mathrm{Sr}$ and $\mathrm{Ba}$ concentrations relative to the NYT.

Glasses from the Pre-NYT unit TLo are trachytic (Fig. 2) with $1.5 \pm 0.1 \mathrm{wt} \% \mathrm{CaO}$ and the highest $\mathrm{SiO}_{2}$ and $\mathrm{Na}_{2} \mathrm{O}$ among the studied Pre-NYT units $(63.9 \pm 0.4$ $\mathrm{wt} \% \mathrm{SiO}_{2}$ and $6.0 \pm 0.3 \mathrm{wt} \% \mathrm{Na}_{2} \mathrm{O}$, respectively). The TLo glasses differ from those of the other NYT-series units, they are highly evolved ( $\mathrm{Sr} / \mathrm{Zr}=30-59)$, have larger feldspar related anomalies $\left(E u / E^{*}{ }_{N}=0.32 \pm 0.04, S r / \operatorname{Pr}_{N}=0.011 \pm 0.04\right)$ and contain higher concentrations of other incompatible elements (Fig 4,5). The TLo can be distinguished from the NYT on the basis that it has significantly higher HFSE and Th concentrations (Fig 5a,b).

In summary:

1. It is extremely difficult to distinguish products of the Pre-NYT eruptions from the NYT using major and trace element geochemistry.

2. The trachytic component of the NYT-LM1 overlaps with the Pre-NYT units $\mathrm{PRa}, \mathrm{VRb}$ and the trachytic population of VRa.

3. The phono-trachytic component of the NYT-LM (LM3 and LM13) overlaps with the phono-trachytic component of Pre-NYT unit VRa.

4. VRa is distinctive among the studied Pre-NYT eruptions as it is bimodal. It can be distinguished from the other studied Pre-NYT units on the basis of slightly higher $\mathrm{MgO}$ and $\mathrm{FeO}$ and lower $\mathrm{Ba}$ and $\mathrm{Sr}$.

5. Glasses from the Pre-NYT units have slightly lower $V$ concentrations than those from the NYT deposits.

6. The compositional overlap within the Pre-NYT coupled with the number of Pre-NYT units, mean that it is difficult to distinguish between the Pre-NYT eruptions.

7. TLo is clearly distinguished from the other Pre-NYT units studied herein, but indicates the occurrence of more evolved Pre-NYT magmas.

\subsection{Cl-series ( $\mathrm{Cl}$, Pre-Cl)}

Pre- $\mathrm{Cl}$ and $\mathrm{Cl}$ glasses have a narrow range of $\mathrm{CaO}, \mathrm{MgO}, \mathrm{FeO}, \mathrm{TiO}_{2}$ (1.3-2.2, 0.26-0.52, 2.4-3.5 and 0.34-0.46 wt\%, respectively) for a wide range of $\mathrm{SiO}_{2}$ contents (55-63 wt\%) (Fig. 3). Concentrations of $\mathrm{SiO}_{2}, \mathrm{Al}_{2} \mathrm{O}_{3}$ and $\mathrm{K}_{2} \mathrm{O}$ are clustered within the Pre- $\mathrm{Cl}$ units and the $\mathrm{Cl}$ fall deposits. Within these units, $\mathrm{K}_{2} \mathrm{O}$ and $\mathrm{Al}_{2} \mathrm{O}_{3}$ decrease with increasing $\mathrm{SiO}_{2}$; this trend continues in a stepwise manner through the studied Pre- $\mathrm{Cl}$ units to the $\mathrm{Cl}$. Chlorine and $\mathrm{Na}_{2} \mathrm{O}$ are also clustered and show a positive correlation, but are slightly higher in the Pre-Cl samples relative to $\mathrm{Cl}$. In contrast to the Pre-Cl units and the $\mathrm{Cl}$ fall, glasses from the $\mathrm{Cl}$ lower and intermediate flows have a wider range of $\mathrm{SiO}_{2}$ contents and $\mathrm{SiO}_{2}$ is positively correlated with $\mathrm{Al}_{2} \mathrm{O}_{3}$ and $\mathrm{K}_{2} \mathrm{O}$. Geochemical variation within the $\mathrm{Cl}$ is consistent with mixing between the evolved $\mathrm{Cl}$ magma (erupted as both fall and the lower and intermediate flows) and a less evolved magma (Civetta et al., 
454

455

456

457

458

459

460

461

462

463

464

465

466

467

468

469

470

471

472

473

474

475

476

477

478

479

480

481

482

483

484

485

486

487

488

489

490

491

492

493

494

495

496

497

498
1997; Arienzo et al., 2009). The Cl upper flow, which was deposited at the end of the eruption, is less evolved and isotopically distinct from the rest of the $\mathrm{Cl}$-series (Arienzo et al., 2009).

Incompatible element concentrations define positive linear correlations within the Cl-series (Fig. 5), except for those elements that are depleted during feldspar fractionation ( $\mathrm{Eu}, \mathrm{Sr}, \mathrm{Ba}$ ). Ratios of HFSE to Th are constant within the Cl-series glasses $(\mathrm{Nb} / \mathrm{Th}=2.4 \pm 0.3 ; \mathrm{Zr} / \mathrm{Th}=13 \pm 1 ; \mathrm{Ta} / \mathrm{Th}=0.11 \pm 0.01)$. Relative to the NYT-series, the Cl-series has a higher Th concentration, higher HFSE contents, higher ratios of HFSE to Th, and low $\mathrm{V}$ concentrations (11-26 ppm). The $\mathrm{Cl}-$ series also has larger Eu anomalies $\left(\mathrm{Eu} / \mathrm{Eu}^{*}{ }_{\mathrm{N}}=0.2-0.5\right)$ than in the NYT series. The higher degree of evolution of the $\mathrm{Cl}$-series can also be seen in the ratio $\mathrm{Zr} / \mathrm{Sr}$ $=5-84$ (Fig. 5f).

\section{$5.3 .1 \mathrm{Cl}$}

Glasses from the $\mathrm{Cl}$ fall and from the lower and intermediate flow units straddle the trachyte-phonolite boundary and overlap extensively in major element composition (Fig. 2,3). In terms of trace elements, the fall is compositionally intermediate to evolved, with $\mathrm{Zr} / \mathrm{Sr}=5-31$ (Fig. 5f) and shows negative anomalies in $\mathrm{Sr}\left(\mathrm{Sr} / \mathrm{Pr}_{\mathrm{N}}=0.01-0.08\right)$ and $\mathrm{Eu}\left(\mathrm{Eu} / \mathrm{Eu}^{*}{ }_{\mathrm{N}}=0.24-0.34\right)$ consistent with feldspar fractionation (Fig. 4c). Glasses from the lower and intermediate flow units overlap widely with those from the fall and are also compositionally intermediate to evolved in composition, with $\mathrm{Zr} / \mathrm{Sr}=8-28$. However, glasses from the lower and intermediate flows lack the most enriched compositions present in the $\mathrm{Cl}$ fall and feldspar related anomalies are not so prominent $\left(\mathrm{Sr} / \mathrm{Pr}_{\mathrm{N}}=0.01-0.04 ; \mathrm{Eu} / \mathrm{Eu}^{*}{ }_{\mathrm{N}}=\right.$ $0.27-0.36$ ). Concentrations of incompatible elements that are not affected by feldspar fractionation are typically lower in glasses from the lower and intermediate flows ( $\mathrm{Th}=41-51, \mathrm{Ba}=15-65 ; \mathrm{Nb}=13-117)$ than in the fall $(\mathrm{Th}=$ 41-62; $\mathrm{Ba}=13-105 ; \mathrm{Nb}=13-136$ ) components of the $\mathrm{Cl}$. The fall and flow (lower and intermediate) can be most clearly distinguished on a plot of Zr-Th (Fig. 6).

The magma feeding the $\mathrm{Cl}$ upper flow unit is distinctive from the magma feeding the underlying fall and flows, as it is a trachyte (Fig. 2). The $\mathrm{Cl}$ upper flow glasses have higher concentrations of $\mathrm{CaO}, \mathrm{MgO}, \mathrm{K}_{2} \mathrm{O}(2.5,0.76$ and $8.1 \mathrm{wt} \%$, respectively) and $\mathrm{V}(<64 \mathrm{ppm})$, and lower $\mathrm{Na}_{2} \mathrm{O}(2.8-4.9 \mathrm{wt} \%)$ than the $\mathrm{Cl}$ fall and lower/intermediate flows (Fig. 3,5). They have ratios of $\mathrm{Na}_{2} \mathrm{O} / \mathrm{K}_{2} \mathrm{O}<0.6$. The analysed glasses extend to poorly evolved compositions with $\mathrm{Zr} / \mathrm{Sr}=0.4$ and negligible $\mathrm{Eu}$ and $\mathrm{Sr}$ anomalies $\left(\mathrm{Eu}_{\mathrm{Eu}}{ }^{*} \mathrm{~N}=1.1\right.$; $\left.\mathrm{Sr} / \mathrm{Pr}_{\mathrm{N}}=0.7\right)$. Ratios of HFSE to Th are higher than for the glasses from the $\mathrm{Cl}$ fall and lower and intermediate flows and are transitional, with more evolved samples plotting close to the $\mathrm{Cl}$ fall and lower/intermediate flow compositions and a less evolved magma composition.

In summary, the $\mathrm{Cl}$ analysed glasses are characterised by the following features: 
1. Glasses from the fall and the lower and intermediate flows straddle the phono-trachyte boundary and those from the upper flow are trachytic in composition (e.g. Arienzo et al., 2009; Civetta et al., 1997; Pappalardo et al., 2002a).

2. Glasses from the fall and the lower and intermediate flows have overlapping compositions and show a continuous range from intermediate to evolved compositions, with the flows extending to less evolved compositions. They can be separated on a plot of Zr-Th.

3. Glasses from the upper flow span a range between the $\mathrm{Cl}$ fall and a less differentiated end-member composition and have $\mathrm{Na}_{2} \mathrm{O} / \mathrm{K}_{2} \mathrm{O}<0.6$.

\subsubsection{Pre-Cl}

Pre-Cl units (youngest to oldest) TLf, TLc and TLa $\left(58 \pm 3{ }^{40} \mathrm{Ar} /{ }^{39} \mathrm{Ar}\right.$ ka; Pappalardo et al., 1999) all have narrow compositional ranges in both major and trace elements (Fig. 3, 5), as previously shown by Pabst et al. (2008) on the basis of whole rock compositions. Glasses from the Pre-Cl units are phonolitic (Fig. 2) and are distinct from $\mathrm{Cl}$ eruption glasses in terms of major element composition. The Pre- $\mathrm{Cl}$ units are characterised by low $\mathrm{SiO}_{2}$ and high $\mathrm{CaO}, \mathrm{FeO}$ and $\mathrm{Al}_{2} \mathrm{O}_{3}$ concentrations relative to the $\mathrm{Cl}$. In addition, $\mathrm{Na}_{2} \mathrm{O}$ is higher in the Pre$\mathrm{Cl}$ units than in the fall and flows of the $\mathrm{Cl}$. The incompatible elements enrichment in the Pre-Cl units decreases in the order TLa>TLc>TLf (Fig. 4d).

The TLf is the last large unit deposited prior to the eruption of the $\mathrm{Cl}$. Relative to the other Pre- $\mathrm{Cl}$ units analysed, the TLf glasses have higher $\mathrm{MgO}$ contents and higher $\mathrm{K}_{2} \mathrm{O}$ and higher but overlapping $\mathrm{SiO}_{2}$ and have lower $\mathrm{Na}_{2} \mathrm{O}$ and lower but overlapping $\mathrm{FeO}$ (Fig 3 ). In terms of trace element composition, TLf glasses are moderately evolved $(\mathrm{Zr} / \mathrm{Sr}=8-22)$ and have a smaller Eu anomaly $\left(\mathrm{Eu} / \mathrm{Eu}^{*} \mathrm{~N}=\right.$ $0.45 \pm 0.06$ ) and lower Th and HFSE element concentrations than TLa and TLC. TLf overlaps with the $\mathrm{Cl}$ evolved component in terms of incompatible element composition, but differs in major elements.

The TLc glasses have the lowest $\mathrm{SiO}_{2}$ content of the Pre-Cl units analysed (58.6 $\pm 0.4 \mathrm{wt} \%)$. They are compositionally moderately evolved with moderate feldspar related anomalies $\left(\mathrm{Zr} / \mathrm{Sr}=41-58, \mathrm{Eu} \mathrm{Eu}^{*}{ }_{\mathrm{N}}=0.31 \pm 0.03\right)$. The TLc glasses overlap strongly with TLa glasses in both major and trace element composition (Fig. 3,5), the main differences being that TLc glasses have higher $\mathrm{Al}_{2} \mathrm{O}_{3}(19.8 \pm$ $0.3 \mathrm{wt} \%)$, higher but overlapping Th and lower but overlapping ratios of HFSE to $\mathrm{Ti}(\mathrm{Zr} / \mathrm{Ti}=0.32 \pm 0.02 ; \mathrm{Nb} / \mathrm{Ti}=0.063 \pm 0.003 ; \mathrm{Y} / \mathrm{Ti}=0.025 \pm 0.001)$.

The TLa glasses are intermediate between TLc and TLf for all major elements except that it has lower $\mathrm{Al}_{2} \mathrm{O}_{3}(19.6 \pm 0.3 \mathrm{wt} \%)$. The TLa glasses show a similar

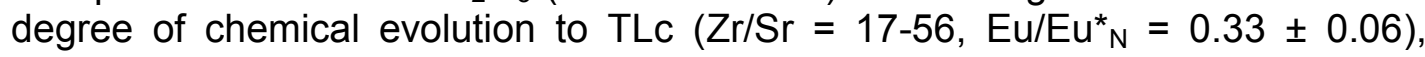
except for lower $\mathrm{Al}_{2} \mathrm{O}_{3}(19.6 \pm 0.3 \mathrm{wt} \%)$ and higher but overlapping ratios of HFSE to $\mathrm{Ti}(\mathrm{Zr} / \mathrm{Ti}=0.34 \pm 0.01 ; \mathrm{Nb} / \mathrm{Ti}=0.066 \pm 0.004 ; \mathrm{Y} / \mathrm{Ti}=0.027 \pm 0.001)$. 
In summary:

1. The Pre-Cl units TLa, TLc and TLf are clearly distinguished from the $\mathrm{Cl}$ on the basis that they are phonolitic, while the $\mathrm{Cl}$ is phonolite-trachyte and have lower $\mathrm{SiO}_{2}$ and higher $\mathrm{CaO}, \mathrm{FeO}$ and $\mathrm{Al}_{2} \mathrm{O}_{3}$ concentrations.

2. The Pre-Cl units TLa and TLC are similar in major and trace element composition but can be distinguished from each other on the basis of $\mathrm{SiO}_{2}, \mathrm{Al}_{2} \mathrm{O}_{3}$, Th and ratios of HFSE to $\mathrm{Ti}$.

3. The Pre-Cl unit TLf is distinct from TLa and TLc, it has lower Th, Nb, Y, Zr, and larger Eu anomalies

4. The possible presence of other Pre-Cl units in distal locations means that it may be difficult to confidently distinguish between Pre-Cl units.

\subsection{Comparing the NYT- and Cl-series}

The Cl-series (60-39 ka) and the NYT-series/PP (39-12 ka) can be distinguished using both major and trace element compositions. The most diagnostic criteria are:

1. The NYT-series have higher ratios of $\mathrm{CaO} / \mathrm{SiO}, \mathrm{MgO} / \mathrm{SiO}$ and $\mathrm{TiO}_{2} / \mathrm{SiO}_{2}$ and lower $\mathrm{Al}_{2} \mathrm{O}_{3} / \mathrm{SiO}_{2}$ ratios and lower $\mathrm{Na}_{2} \mathrm{O}, \mathrm{Cl}$ and $\mathrm{MnO}$ concentrations relative to the $\mathrm{Cl}$-series.

2. Ratios of HFSE to Th distinguish members of the NYT-series $(\mathrm{Nb} / \mathrm{Th}=1.7$ $\pm 0.1 ; \mathrm{Zr} / \mathrm{Th}=10.9 \pm 0.6 ; \mathrm{Ta} / \mathrm{Th}=0.08 \pm 0.01)$ and the $\mathrm{Cl}$-series $(\mathrm{Nb} / \mathrm{Th}=$ $2.4 \pm 0.3 ; \mathrm{Zr} / \mathrm{Th}=13 \pm 1 ; \mathrm{Ta} / \mathrm{Th}=0.11 \pm 0.01$ ).

3. The $\mathrm{Cl}$-series $(\mathrm{Zr} / \mathrm{Sr}=5-84)$ is significantly more evolved than the NYTseries $(\mathrm{Zr} / \mathrm{Sr}=0.2-7)$.

4. Feldspar fractionation signatures are typically larger in the Cl-series $\left(\mathrm{Eu} \mathrm{Eu}^{*}{ }_{\mathrm{N}}=0.2-0.5\right)$ than the NYT-series $\left(\mathrm{Eu} / \mathrm{Eu}^{*}{ }_{\mathrm{N}}=0.3-1.0\right)$.

5. Vanadium concentrations are higher in the NYT-series (20-170 ppm) relative to the $\mathrm{Cl}$-series (11-26 ppm).

The NYT-series and Cl-series trends appear to converge at the least evolved compositions (low incompatible element concentrations) on trace element plots (Fig.5a-d). Glass compositions from the $\mathrm{Cl}$ upper flow extend between the $\mathrm{Cl}$ fall and a composition similar to the least evolved NYT-series magma. Ratios of HFSE to Th in the $\mathrm{Cl}$ upper flow are lower than for the rest of the Cl-series (Table 5 ) and are also transitional between the $\mathrm{Cl}$ - and NYT-series.

\section{DISCUSSION}

\subsection{Proximal-distal correlation with Lago Grande di Monticchio tephra}

In the following sections, we compare the proximal data to new major and trace element data for tephra in the medial-distal Lago Grande di Monticchio archive (Table 4). We use the diagnostic geochemistries defined proximally and, in some cases at Lago Grande di Monticchio, to assess distal occurrences of Phlegraean 
591

592

593

594

595

596

597

598

599

600

601

602

603

604

605

606

607

608

609

610

611

612

613

614

615

616

617

618

619

620

621

622

623

624

625

626

627

628

629

630

631

632

633

634

635

636

Fields tephra in the literature. This allows an improved understanding of the dispersal of tephra from PP, NYT and Cl. A summary of tephra dispersal characteristics is given in table 6 .

\subsubsection{Pomici Principali (PP) \& C-1/TM-7b}

Major and trace element analyses indicate that the PP can be distinguished from the NYT-series tephras on the basis of lower $\mathrm{MgO}$ and $\mathrm{FeO}$ for a given $\mathrm{SiO}_{2}$ concentration (Fig 3b,c). Trace element compositions of the PP and NYT-series overlap widely (Fig. 4a).

The PP is correlated with TM-7b in Lago Grande di Monticchio (Narcisi, 1996; Wulf et al., 2004; Smith et al., 2011). Major and trace element data for TM-7b glasses is given in table 4. TM-7b glasses show a good match with PP for all trace element ratios, including HFSE/Th and elements affected by plagioclase crystallisation ( $\mathrm{Sr}, \mathrm{Ba}, \mathrm{Eu}$ ) supporting a proximal-distal correlation (Fig.6a). The TM-7b glass analyses span a narrower compositional range than the PP glasses sampled at Via Pigna (Fig. 3-5, 7a).

The PP has been linked to tephra $\mathrm{C}-1$ in marine cores from the South Adriatic (Paterne et al., 1988; Siani et al., 2004; Calanchi et al., 2008). The tephra compositions reported by Siani et al. (2004) and Calanchi et al. (2008) overlap with the proximal datasets reported herein and in Smith et al. (2010) and with Lago Grande di Monticchio tephra TM-7b (Fig. 8a). The C-1 tephra of Paterne et al. (1988) is more evolved than the proximal samples, but lies on the PP trend with respect to $\mathrm{MgO}-\mathrm{SiO}_{2}$ (Fig. 8a) and is considered to have been sourced from the PP eruption. In contrast, reported occurrences of C-1/PP tephra in the central Adriatic (Bourne et al., 2010; Calanchi et al., 2008) do not correlate with the proximal PP reported here or by Smith et al. (2010). Bourne et al. (2010) report a cryptotephra layer from a central Adriatic core which comprises tephra from both the NYT and PP eruptions, however the reported data all lie on the higher MgO$\mathrm{SiO}_{2}$ trend of the NYT, Bourne (2012) later correlated this layer with TM-8, rather than TM-7b on the basis of further data. Calanchi et al. (2008) report a tephra in a central Adriatic core, whose geochemistry differs significantly from the proximal PP and TM-7b. The authors linked this tephra to PP on the basis that it is comparable to TM-7a, however this LGM tephra is does not have a PP chemistry (Wulf et al., 2004). The composition of TM-7a overlaps with the NYT-series in $\mathrm{MgO}-\mathrm{SiO}_{2}$. PP is not documented in any Tyrrhenian Sea cores in the study of Paterne et al. (1988). Therefore, we suggest that the PP has not yet been found in the central Adriatic and marine occurrences of the PP are currently confined to the south Adriatic.

The PP tephra has also been reported in terrestrial cores, Lake Bled (Slovenia, Lane et al., 2011), Lake Shkodra (Albania and Montenegro, Sulpizio et al., 2010) and Lake Accesa (Italy, Mangy et al., 2006). In Lake Bled, 620 km north of Phlegraean Fields, a cryptotephra correlated to PP shows a good overlap with 
637 the proximal data reported here and extends to more evolved compositions 638 (Fig.7a), suggesting that the PP magma spans a wider compositional range than 639 is represented proximally. The reported mean composition of the Lake Shkodra 640 tephra, from a location $440 \mathrm{~km}$ east of the Phlegraean Fields, does not lie on the 641 PP compositional trend and appears more similar to the NYT-series glasses 642 reported herein. The age of the layer at lake Shkodra is poorly constrained 643 (Sulpizio et al., 2010). Finally, Magny et al. (2006) report two distinct tephra 644 layers with characteristics similar to the PP tephra in a core from Lake Accesa, 645 Italy, but neither PP1 nor PP2 is comparable to the proximal PP glass compositions.

This re-examination of distal occurrences of the PP suggests that the areal extent of this tephra is limited. The presence of PP tephra in the south Adriatic and absence in the central Adriatic indicates that the PP was dominantly distributed to the east. However, the occurrence of cryptotephra in Lake Bled indicates some dispersal to the north. Distal settings appear to preserve more evolved compositions than are known from the proximal deposits.

\subsubsection{The Neapolitan Yellow Tuff (NYT) \& C-2/TM-8}

Major and trace element analyses of proximal glasses indicate that the NYT tephra may be distinguished from the trachytic, geochemically similar Pre-NYT 659 tephras, on the basis of the occurrence of less evolved phono-trachytic 660 compositions, either representing the less differentiated cluster at $57.5-58.5 \mathrm{wt} \%$ $661 \mathrm{SiO}_{2}$ (NYT-LM) and/or the less differentiated portion (down to $56.0 \mathrm{wt} \% \mathrm{SiO}_{2}$ ) of 662 the continuous trend (NYT-UM). The Pre-NYT VRa layer is also bimodal with a 663 phono-trachytic component, but the NYT is separated on the basis of lower $\mathrm{CaO}$ 664 and $\mathrm{FeO}$ (Fig. 3a,c) and higher $\mathrm{Ba}$ and $\mathrm{Sr}$. In the following section we assess 665 previously correlated occurrences of the NYT tephra in terms of the dispersal of 666 the LM and UM components.

667

668 The NYT has been correlated with the Lago Grande di Monticchio tephra TM-8 669 (Wulf et al., 2004). The TM-8 glasses (Table 4) have two modes (61.5-62 wt\% $670 \mathrm{SiO}_{2}$ and $56.0-58.4 \mathrm{wt} \% \mathrm{SiO}_{2}$ ). The high-SiO${ }_{2} \mathrm{TM}-8$ glasses show a good match 671 to the high-SiO ${ }_{2}$ cluster in the NYT-LM, while low-SiO ${ }_{2}$ TM-8 glasses overlap with 672 the low-SiO ${ }_{2}$ cluster in the NYT-LM. The TM-8 glass compositions extend to less 673 evolved, tephra-phonolitic compositions (lower $\mathrm{SiO}_{2}, \mathrm{~K}_{2} \mathrm{O}, \mathrm{Na}_{2} \mathrm{O}$ and higher $\mathrm{FeO}$, $674 \mathrm{MgO}$ and $\mathrm{CaO}$; Fig. 3) with higher $\mathrm{Ba}$ and $\mathrm{Sr}$ concentrations and lower $\mathrm{Zr} / \mathrm{Sr}$ 675 ratios (Fig. 5) consistent with the NYT-UM and there are some shards of 676 intermediate composition (58-61 $\left.\mathrm{wt} \% \mathrm{SiO}_{2}\right)$, which are also associated with the 677 NYT-UM. Therefore, both phases of the NYT eruption are recorded at Lago 678 Grande di Monticchio (Fig. 7b,c).

679

680

681

682

The NYT has been correlated to marine tephra C-2 in distal settings up to $250 \mathrm{~km}$ from the Phlegraean Fields in the Tyrrhenian and Adriatic Seas (Paterne et al., 1988; Bourne et al., 2010; Calanchi et al., 1998; Siani et al., 2004). C-2 is dated 
683

684

685

686

687

688

689

690

691

692

693

694

695

696

697

698

699

700

701

702

703

704

705

706

707

708

709

710

711

712

713

714

715

716

717

718

719

720

721

722

723

724

725

726

727

728 at 13.84-14.88 cal ka BP in Adriatic core MD90-917. In each of the Tyrrhenian and Adriatic marine cores, the C-2 layer is characterised by the presence of lowsilica glasses $\left(<57.5 \mathrm{wt} \% \mathrm{SiO}_{2}\right)$ and by a differentiation trend from phonotrachytic, low-SiO ${ }_{2}$ to phonolitic, high-SiO ${ }_{2}$ compositions (Paterne et al., 1988; Bourne et al., 2010; Calanchi et al., 1998; Siani et al., 2004). This is consistent with a correlation to the NYT rather than any of the geochemically similar PreNYT layers. Specifically, distal occurrences of NYT tephra in the Tyrrhenian Sea to the west and south-west of Phlegraean Fields and the Adriatic Sea to the east and north-east of Phlegraean Fields may record both the NYT-LM and NYT-UM (Fig.7b). This is clear in the PRAD218 central Adriatic core (Bourne et al., 2010) because compositional data is given for individual glass shards, allowing both the NYT-UM trend and the NYT-LM low- and high $\mathrm{SiO}_{2}$ clusters to be seen. The C-2 tephra data of Paterne (1988), Calanchi et al., (1998) and Siani et al., (2004) appear to be dominated by the NYT-UM, but this is not clear because only mean tephra compositions are given, masking the compositional range and possibly the actual magma comopostion.

The NYT tephra has been identified in terrestrial cores from Lake Bled (Slovenia, Lane et al., 2011) and Längsee, Austria (Schmidt et al., 2002), approximately 620 and $650 \mathrm{~km}$ north of Phlegraean Fields, respectively. The correlated tephra layers are bimodal, with clusters overlapping the phono-trachytic and trachytic populations in the NYT-LM (Fig.7b).

Both the bimodal NYT-LM and the continuous NYT-UM occur in distal localities. The NYT-UM is expected to form thicker tephra layers on the basis of its larger relative volume. The NYT-UM is the dominant NYT tephra in settings to the east and west of the Phlegraean Fields. However, the NYT-LM is found in the absence of the NYT-UM in locations (to date) up to $650 \mathrm{~km}$ north of the Phlegraean Fields.

\subsubsection{Pre-NYT}

Numerous eruptions punctuate the time period between the $\mathrm{Cl}$ and NYT events, five are recorded at Trefola and Verdolino, and nine at Ponti Rossi (Orsi et al., 1996). We have analysed four of these Pre-NYT units, the data indicates that this phase of Phlegraean Fields activity is characterised by repeated eruption of very similar trachytic magmas. Tephra from the Pre-NYT eruptions may be widely dispersed, at least 10 Pre-NYT tephra layers are recorded in the Lago Grande di Monticchio core, with TM-9 and TM-15 being the most prominant (Wulf et al., $2004 ; 2007 ; 2008)$. Several important distal tephra layers correlated with Phlegraean Fields fall in the Pre-NYT/Tufi Biancastri time window, including GM1, Lagno Amendolare and Y-3. Siani et al. (2004) propose that some previously recognised occurrences of the C-2 tephra layer (NYT) may correlate with GM1, or may contain more than a single tephra, because the close chronology of these events makes them difficult to distinguish stratigraphically. 
6.1.3.1 TM-9/GM1 has previously been linked (Wulf et al., 2004) to the youngest ka (Pappalardo et al., 1999), which was not analysed in this study.

The TM-9 is a $2 \mathrm{~cm}$ thick tephra layer with a varve age of $14.56 \mathrm{ka}$ BP from Lago Grande di Monticchio (Wulf et al., 2004, 2008). New major and trace element data for TM-9 glasses are given in Table 4 . The major $(\mathrm{FeO} / \mathrm{CaO})$ and trace (HFSE/Th: Fig. 5) element ratios of TM-9 glasses are consistent with the NYT series. Like the proximal Pre-NYT units studied here, the TM-9 glass displays a narrow range of major $\left(1.85-1.99 \mathrm{wt} \% \mathrm{CaO}, 62.1-63.1 \mathrm{wt} \% \mathrm{SiO}_{2}\right)$ and trace element compositions. However, TM-9 has higher incompatible trace element concentrations (HFSE and Th) and lower V, Ba and Sr concentrations than any of the similar proximal Pre-NYT products studied here (Fig. 3, 5). When compared to whole rock data for proximal unit PRe (Pappalardo et al., 1999), TM-9 appears to be similar, and lower $\mathrm{SiO}_{2}, \mathrm{Na}_{2} \mathrm{O}, \mathrm{Rb}$ and $\mathrm{Nb}$ and higher $\mathrm{FeO}$, $\mathrm{K}_{2} \mathrm{O}, \mathrm{V}$ and $\mathrm{Ba}$ may be within error given the differing analytical techniques, however glass geochemical data is required to fully assess the TM-9 - PRe correlation suggested by Wulf et al. (2004).

TM-9 has been linked to GM1 (Wulf et al. 2004). GM1 is thought to be sourced from the Phlegraean fields, but its type locality is a layer on the slopes of Somma-Vesuvius, where it occurs stratigraphically above the Lagno Amendolare deposits (Andronico et al., 1996; Zanchetta et al., 2000). Tephra layers correlated to GM1 are described from the Adriatic Sea, where two layers (14.7 and $15.5 \mathrm{cal}$ ka BP) are found below the C-2/NYT layer (Siani et al., 2004), and from Lake Prespa, Albania where two layers are also described (Aufgebauer et al., 2012). Our data from TM-9 reveals higher $\mathrm{Na}_{2} \mathrm{O}$ and lower $\mathrm{K}_{2} \mathrm{O}$ relative to published compositions of the GM1 type-site and distal GM1 tephra (Fig.7c,d), therefore we suggest that TM-9 and GM1 may not represent the same Pre-NYT event.

6.1.3.2 Lagno Amendolare/TM-10 The type-site for Lagno Amendolare is an outcrop on the northern flank of Vesuvius, and is characterized by a mix of light and dark coloured pumice and dated at 15.2-16.5 cal ka BP (Andronico et al., 1996). A tephra that is correlated to TM-10 is described in the Adriatic Sea (Siani et al., 2004; Bourne et al., 2010) where it is dated at 16.1-16.9 cal ka BP (Siani et al., 2004). This layer was not analysed in this study and is not discussed here.

6.1.3.3 Y-3/TM-15 has previously been linked (Wulf et al., 2004) to the Pre-NYT Tufi Biancastri unit VRa (Di Vito et al., 2008) sampled in this study and dated at $30.3 \pm 0.2{ }^{40} \mathrm{Ar}{ }^{39} \mathrm{Ar}$ ka (Pappalardo et al., 1999).

TM-15 is a $29 \mathrm{~cm}$ thick tephra layer with a varve age of $27.26 \mathrm{ka}$ BP from Lago Grande di Monticchio. New major and trace element data for TM-15 glasses are given in Table 4. The major $(\mathrm{FeO} / \mathrm{CaO})$ and trace $(\mathrm{HFSE} / \mathrm{Th})$ element ratios of TM-15 glasses (Table 4) are consistent with the Pre-NYT series. TM-15 glasses have higher $\mathrm{MgO}$ and $\mathrm{FeO}$ for a given $\mathrm{SiO}_{2}$ (Fig. 3), consistent with $\mathrm{VRa}$ and 
partially overlap with the trachytic component of the bimodal VRa (the lower part and to higher $\mathrm{K}_{2} \mathrm{O}$ and to higher HFSE concentrations (Fig.6d). Therefore, we cannot confirm a correlation between VRa and TM-15. Furthermore TM-15 lacks a phono-trachytic component, but this may be an artefact of sampling from the base of the visible tephra layer.

TM-15 has been linked to the distal Y-3 tephra, first described from an lonian Sea core (Keller 1978). The average major element data of $\mathrm{Y}-3$ from the type-site (Keller et al., 1978) overlaps with the TM-15 field defined in this study (Fig.7e,f). Y-3 tephra has also been described from a number of locations in the Mediterranean basin, including the Balkans (Wagner et al., 2008; Caron et al., 2010) and in the Adriatic (Zanchetta et al., 2008; Calanchi et al., 1998; Bourne et al., 2010), Ionian (Kraml, 1997) and Tyrrhenian (Munno and Petrosino, 2004; Paterne et al., 1988) Seas. Of these studies, only the Tyrrhenian Sea data fall within the compositional field of TM-15, while the Adriatic Sea data of Bourne et al., (2010) lie on the same high-FeO and MgO trends but do not overlap with the type site Y-3 type site of Keller (1978). It is possible that further correlations are masked by averaged datasets, however some layers previously linked to Y-3 and/or TM-15 may be related to one or more of the other Pre-NYT eruptions.

\subsubsection{Campanian Ignimbrite (CI) \& Y5/TM-18}

The phono-trachytic $\mathrm{Cl}$ is clearly distinct from the trachytic Pre-Cl magmas and has lower $\mathrm{CaO}$ and $\mathrm{K}_{2} \mathrm{O}$ and higher $\mathrm{Na}_{2} \mathrm{O}$ relative to the younger NYT-series magmas.

The $\mathrm{Cl}$ is correlated with tephra layer TM-18 in Lago Grande di Monticchio (Narcisi, 1996; Wulf et al., 2004). The TM-18 layer comprises a $17 \mathrm{~cm}$ thick basal pumice fall layer overlain by a $9 \mathrm{~cm}$ thick layer of vitric ash, interpreted as the coignimbrite fall deposit generated during the flow phase of the $\mathrm{Cl}$ eruption by Narcisi (1996) and Wulf et al. (2004). We have analysed the major and trace element composition glasses from of both the basal pumice and the vitric ash components of layer TM-18, here termed TM-18 base and TM-18 top, respectively (Table 4). Compositions of TM-18 base glasses match that of samples from the $\mathrm{Cl}$ fall (Fig. 6, 7f), while TM-18 top glasses overlap completely with the tephra sampled from the proximal $\mathrm{Cl}$ lower and intermediate flows (Fig. $6,7 e)$.

The $\mathrm{Cl}$ is correlated with the $\mathrm{Y}-5$ ash layer, which is recognised from marine cores across the Eastern Mediterranean (e.g. Cornell et al., 1983; Keller et al., 1978) and the C-13 layer in the Tyrrhenian Sea (Paterne et al., 1988, Ton-That et al., 2001). The $\mathrm{Cl}$ is found in terrestrial sites as far as Russia, $\sim 2500 \mathrm{~km}$ from the source (Pyle et al., 2006; Giaccio et al, 2008). Costa et al. (2012) have modelled the $\mathrm{Cl}$ dispersal and show that $>3.7$ million $\mathrm{km}^{2}$ was covered by $>5 \mathrm{~mm}$ of ash. The Y-5 tephra is significant from both a climatic viewpoint as it occurs near the 
start of Heinrich event 4 (Ton-That et al., 2001) and an archaeological perspective as it occurs within the timeframe of the European Middle to Upper Palaeolithic transition ( 40 ka BP, Fedele et al., 2008). Recorded occurrences of the Y-5 tephra have a bimodal size distribution in some sites up to $1500 \mathrm{~km}$ from the source (Cornell et al., 1983; Sparks and Huang, 1980), which may correspond to both the fall and dilute pyroclastic current phases of the $\mathrm{Cl}$ eruption. The computational model of Costa et al. (2012) indicates that most of the tephra dispersal was associated with the dilute pyroclastic density current phase of the $\mathrm{Cl}$ eruption.

Published bulk trace element compositions of distal $\mathrm{Cl}$ tephra fall from the Aegean (Hardiman et al., 1999; Pyle et al., 2006) and Tyrrhenian (Paterne 1988; Ton-That et al., 2001) seas and from continental settings in Lesvos, Greece (Margari et al., 2007), Dobrogea, Romania (Veres et al., 2012), lakes Ohrid and Prespa, Macedonia (Sulpizio et al., 2010); Crvena Stijena, Montenegro (Morley and Woodward 2011) and Kostenki-Borschevo, Russia (Pyle et al., 2006) lie close to the boundary between $\mathrm{Cl}$ fall and $\mathrm{Cl}$ lower and intermediate flow on plots of $\mathrm{Zr}$-Th. Therefore it is not possible to determine whether the fall or flow phase is dominant in these locations. However, these discriminators provide the possibility of further detailing the dispersal of the two main phases of the $\mathrm{Cl}$ eruption, as full trace element glass datasets become available for distal occurrences of $\mathrm{Cl}$ tephra.

The upper flow, represented by the samples from San Marco Evangelista quarry (this work and Arienzo et al., 2009), is considered to have been produced by the last and least energetic eruptive phase of low volume $\left(\sim 20 \mathrm{~km}^{3}\right)$ and high viscosity magma (Civetta et al., 1997). Proximally, the $\mathrm{Cl}$ upper flow is restricted mainly to the Campanian Plain, but may have fuelled detached, dilute coignimbrite clouds that carried ash distally. A single TM-18 top shard from the distal Lago Grande di Monticchio corresponds to the composition of the $\mathrm{Cl}$ upper flow. More distally, Sulpizio et al., (2010) report the occurrence of three differently evolved trachytic magmas in Lakes Ohrid and Prespa (Macedonia), one of which corresponds to the upper flow. However, the upper flow is not widely reported in distal settings. We use the ratio of $\mathrm{Na}_{2} \mathrm{O} / \mathrm{K}_{2} \mathrm{O}<0.6$ to distinguish the $\mathrm{Cl}$ Upper Flow in published datasets of distal $\mathrm{Cl}$ tephra, in cases where compositional data is given for individual glass shards. $\mathrm{Cl}$ upper flow tephra is present at KostenkiBorschevo, Russia (Pyle et al., 2006), Dobrogea, Romania (Veres et al., 2012), Crvena Stijena, Montenegro (Morley and Woodward 2011), Lakes Ohrid and Prespa, Macedonia (Sulpizio et al., 2010, Caron et al., 2010, Wagner et al., 2008, Vogel et al., 2010), Lesvos, Greece (Margari et al., 2007) and Philippi, Greece (St.Seymour et al., 2004). In most cases, the Cl upper flow only constitutes a minor proportion of the population of $\mathrm{Cl}$ tephra shards and its presence in other localities may be masked in averaged datasets. Our analysis of published datasets suggests that the $\mathrm{Cl}$ upper flow is widely present.

\subsubsection{Pre-Campanian Ignimbrite}


The Pre-Cl units described here (TLa, TLc and TLf from Trefola) all have restricted compositional ranges and can be distinguished from the $\mathrm{Cl}$ on the basis of major element composition.

Many of the Pre-Cl tephra are likelyd to be widely dispersed across the Mediterranean because of their proximal thicknesses and eastward dispersal (Di Vito et al., 2008). West of the Apennines, TLc in the Trefola Quarry has been linked to the Santa Lucia fall deposits with an age $50.95 \pm 2.98$ cal ka BP on the basis of glass major and whole rock trace element data (Di Vito et al., 2008). The Santa Lucia deposits are widespread and thick in the Apennine area and are also reported in the Camaldoli della Torre core (Santa Lucia) from the southern slopes of Somma-Vesuvius (Di Renzo et al., 2007). However, the EDS glass data for Santa Lucia (Di Vito et al., 2008) differs significantly from the TLc data presented here, having higher $\mathrm{CaO}, \mathrm{K}_{2} \mathrm{O}$ and $\mathrm{MgO}$ and lower $\mathrm{Na}_{2} \mathrm{O}$. The trace element composition of Santa Lucia pumices has lower levels of trace element enrichment relative to TLc.

\subsection{Implications for tephra correlations}

This study of proximal glass major and trace element geochemistries from the 60-12 ka eruptive sequence of the Phlegraean Fields highlights several issues of relevance for tephrochronology.

\subsubsection{Exposure}

Incomplete preservation due to erosion and limited exposure in urban areas at proximal localities means that some tephra units preserved distally may not be recognised proximally. For example, we are unable to identify a proximal equivalent of the distal Lago Grande di Monticchio TM-18-4 and TM-15 tephra layers. For this reason, there is a need for high quality major and trace element glass datasets from high-resolution distal archives such as the Lago Grande di Monticchio, and from other type sites in medial-distal locations.

\subsubsection{Stratigraphic variation}

Proximal deposits from the large $\mathrm{Cl}$ and NYT eruptions show compositional variation with stratigraphic height, reflecting heterogeneous magma systems. The range of geochemistries is an additional feature which can be used to characterise a given eruption for the purpose of correlating tephras. For example we are able to distinguish the Plinian fall and dilute pyroclastic flow phases of the $\mathrm{Cl}$, and the lower and Upper Members of the NYT. For this reason, average tephra compositions should not be presented; representative analyses are more informative and whole datasets are desirable. It is critical that samples are taken vertically through distal tephra layers to ensure they are representative. 


\subsubsection{Long lived magma systems}

Both the 60-39 ka (Cl-series) and 39-14 ka (NYT-series) time windows are characterised by magma systems which erupted several times and produced tephra which either overlap extensively or are indistinguishable in composition. This is also observed for the more recent eruptions from the Phlegraean Fields (Smith et al., 2011). Therefore, it is important to consider other close-in-time and geochemically similar magmas from a potential source volcano when assigning proximal-distal and distal-distal tephra correlations. At the Phlegraean Fields, the proximal Pre-NYT units VRa, VRb and PRa cannot be clearly distinguished using major and trace element glass geochemistry. The same holds true for the Pre-Cl TLa and TLc. In the absence of a definitive geochemical fingerprint, good stratigraphic, chronological, sedimentological control is required and additional characteristics of the deposit, such as clast shape, external surface, groundmass texture are also important (e.g. Cioni et al., 2008).

\subsubsection{Petrogenesis}

The consistency of $\mathrm{U}, \mathrm{Th}, \mathrm{Nb}, \mathrm{Ta}, \mathrm{Zr}$, and $\mathrm{Y}$ inter-element ratios (Fig. 5) within the $\mathrm{Cl}$-series glasses indicates that they share a parental magma, in agreement with the findings of Arienzo et al. (2009), D'Antonio et al. (2007), Di Renzo et al. (2011) and Pabst et al. (2008). Differences between the Cl-series magmas primarily reflect differing degrees of differentiation, but there is no systematic increase in the degree of differentiation with time, suggesting that the $\mathrm{Cl}$-series magmas do not reflect a single evolving magma chamber, but instead reflect distinct magma batches which originated from the parental magma at depth and fractionated in separate shallow reservoirs, as shown by Pabst et al. (2008). This excludes the last erupted magma, the $\mathrm{Cl}$ upper flow, which is distinct from other magmas in the $\mathrm{Cl}$-series. Its composition is less differentiated than the $\mathrm{Cl}$ fall and the lower and intermediate flows and defines a mixing trend between the $\mathrm{Cl}$ fall and a less differentiated magma.

The NYT-series and the PP glasses have consistent HFSE/Th ratios and likely share a similar parent. The NYT-series and PP magmas form compositional clusters and do not define a single differentiation trend. However, these younger magmas have lower $\mathrm{U}, \mathrm{Th}, \mathrm{Nb}, \mathrm{Ta}, \mathrm{Zr}$, and $\mathrm{Y}$ concentrations and lower HFSE/ Th ratios (Fig. 5) relative to the $\mathrm{Cl}$-series, indicating that the NYT-series/PP magmas originated from a different parental magma to the older series. These results agree with previous work suggesting isotopically and geochemically different magmas for the Cl-series and the NYT-series/PP (Arienzo et al., 2009; Di Renzo et al., 2007; Di Renzo et al., 2011; Pabst et al., 2008; Pappalardo et al., 1999; Pappalardo et al., 2002a; Pappalardo et al., 2002b; D'Antonio et al., 2007; Tonarini et al., 2004). Understanding the petrogenetic processes operating at the Phlegraean Fields means that we can assign an unknown Phlegraean Fields tephra to the appropriate series, even in the absence of a proximal match, 
because the HFSE/Th ratio is indicative of a certain parental magma (Cl-series magma and NYT-series/PP magma).

Where multiple eruptions produce identical tephra, such as the Pre-NYT, it may be possible to define compositional groups. Pabst et al. (2008) identified three distinct Pre-Cl magma batches thath were erupted sequentially. Bracketing the age of the first and last occurrence of each compositional group may be useful in providing age constraints on an unknown Phlegraean Fields distal tephra. This could be achieved either by dating of proximal samples or using high-resolution distal archives, such as Lago Grande di Monticchio.

\section{CONCLUSIONS}

The 60-12 ka eruptive sequence of Phlegraean Fields offers an ideal case study to investigate proximal-distal tephra correlations because of the large number of eruptions recorded proximally and in the medial-distal Lago Grande di Monticchio core. The micron-beam major and trace element glass dataset presented here indicate that:

1. Cl-series (60-39 ka) and NYT-series/PP magmas (39-12 ka) were derived from geochemically different magmas, in agreement with previous isotopic studies (Di Renzo et al. (2011), and references therein). HFSE/Th and $\mathrm{FeO} / \mathrm{CaO}$ ratios are constant within each series, allowing an unknown Phlegraean Fields tephra to be assigned to the appropriate series, even if the exact proximal equivalent is not known.

2. Tephra from the caldera forming NYT eruption compositionally overlaps with tephra from the smaller Pre-NYT eruptions. The NYT may be distinguished by the presence of the bimodal trachytic and phono-trachytic LM and by the UM, which spans a compositional range between trachyte and phonotrachyte. Assessment of published data for distal occurrences of NYT tephra shows that the UM is the dominant NYT tephra in settings to the east and west of Phlegraean Fields. However, the NYT-LM is found in the absence of the NYT-UM in locations to the far north of Phlegraean Fields.

3. Magma erupted during the caldera forming $\mathrm{Cl}$ event straddle the phonotrachyte and is distinct from the preceding, lower volume Pre-Cl magmas in major and trace element composition. Cl glasses from the Plinian (fall) and the lower and intermediate flow phases of the eruption overlap extensively, but can be separated using a plot of Zr-Th.

4. There is extensive overlap in major and trace element composition within Pre-NYT and within the Pre-Cl, making it extremely difficult to assign proximal-distal and distal-distal correlations. This means that some such correlations may not be correct. For example, we show that the TM-15 layer from Lago Grande di Monticchio is not the distal equivalent of VRa. It may be possible to recognize the compositional group of an unknown 
1003

1004

1005

1006

1007

1008

1009

1010

1011

1012

1013

1014

1015

1016

1017

1018

1019

1020

1021

1022

1023

1024

1025

1026

1027

1028

1029

1030

1031

1032

1033

1034

1035

1036

1037

1038

1039

1040

1041

1042

1043

1044

1045

1046

1047

distal Phlegraean Fields tephra and therefore constrain its stratigraphic position and age.

In addition to insights into the behavior of the magmatic feeding system, proximal-distal tephra correlations of single eruptions are important for the assessment of volcanic hazards, for example zoning of territory in relation to various dangerous eruption phenomena. Proximal-distal tephra correlations allow more precise estimates of the volume of magma extruded during a single eruption and, therefore, the definition of the eruption magnitude and intensity. Knowledge of such parameters for past eruptions of an active volcano is fundamental to evaluation of the effects of such an eruption on the environment and on climate. This is particularly relevant for volcanoes located in densely populated areas, such as the Phlegraean Fields caldera located in the densely inhabited Neapolitan area of southern Italy. The results of this study will contribute to the ongoing improvement of current volcanic hazards assessments (Orsi et al., 2004; 2009; Costa et al., 2009; Selva et al., 2012).

Acknowledgements: This work is funded by the NERC RESET Consortium (NE/E015905/1). This is paper number ROX/0020. The authors wish to thank Roberto Sulpizio and two anonymous reviewers for thorough and constructive feedback; Paul Albert and Chris Satow for useful discussions and Neil Holloway for sample preparation.

\section{REFERENCES}

Arienzo I., Civetta L., Heumann A., Wörner G., and Orsi G. (2009) Isotopic evidence for open system processes within the Campanian Ignimbrite (Campi Flegrei, Italy) magma chamber. B. Volcanol. 71(3), 285-300.

Andronico, D., Calderoni, G., Cioni, R., Donahue, D.J., Marianelli, P., Santacroce, R., Sbrana, A., Sulpizio, R. (1996) An Updated Chronostratigraphic Scheme of the Last 19,000 Years of Vesuvius Magmatic and Eruptive History. EOS, Electronic Supplement to the Member Newspaper of the American Geophysical Union (AGU), November 7 1996, 671-672.

Arienzo I., Heumann A., Wörner G., Civetta L., and Orsi G. (2011) Processes and timescales of magma evolution prior to the Campanian Ignimbrite eruption (Campi Flegrei, Italy). Earth Planet. Sci. Lett. 306(3-4), 217-228.

Arienzo I., Moretti R., Civetta L., Orsi G., and Papale P. (2010) The feeding system of Agnano Monte Spina eruption (Campi Flegrei, Italy): Dragging the past into present activity and future scenarios. Chem. Geol. 270(1-4), 135147.

Aufebauer, A., Panagiotopoulos, K., Wagner, B., Schaebitz, F., Viehberg, F.A., Vogel, H., Zanchetta, G., Sulpizio, R., Leng, M.J. and Damaschke, M. (in press) Climate and environmental change in the Balkans over the last $17 \mathrm{ka}$ recorded in sediments from Lake Prespa (Albania/F.Y.R. of Macedonia/Greece). Quatern. Int. 
1048

1049

1050

1051

1052

1053

1054

1055

1056

1057

1058

1059

1060

1061

1062

1063

1064

1065

1066

1067

1068

1069

1070

1071

1072

1073

1074

1075

1076

1077

1078

1079

1080

1081

1082

1083

1084

1085

1086

1087

1088

1089

1090

1091

1092

1093

Barberi F., Innocenti F., Lirer L., Munno R., Pescatore T., and Santacroce R. (1978) The campanian ignimbrite: a major prehistoric eruption in the Neapolitan area (Italy). B. Volcanol., Vol. 41, 10-31.

Bohrson W. A., Spera F. J., Fowler S. J., Belkin H. E., De Vivo B., and Rolandi G. (2006) Chapter 13 Petrogenesis of the Campanian Ignimbrite: implications for crystal-melt separation and open-system processes from major and trace elements and Th isotopic data. In Developments in Volcanology, 9(C), 249-288.

Bourne A. J., Lowe J. J., Trincardi F., Asioli A., Blockley S. P. E., Wulf S., Matthews I. P., Piva A., and Vigliotti L. (2010) Distal tephra record for the last ca 105,000 years from core PRAD 1-2 in the central Adriatic Sea: implications for marine tephrostratigraphy. Quaternary Sci. Rev., 29(23-24), 3079-3094.

Bourne, A.J., (2012) The late Quaternary tephrochronology of the Adriatic Region: implications for the synchronisation of marine records. University of London, unpublished $\mathrm{PhD}$ Thesis

Brandt U., Nowaczyk N. R., Ramrath A., Brauer A., Mingram J., Wulf S., and Negendank J. F. W. (1999) Palaeomagnetism of Holocene and Late Pleistocene sediments from Lago di Mezzano and Lago Grande di Monticchio (Italy): initial results. Quaternary Sci Rev 18, 961-976.

Brauer A., Mingram J., Frank U., Gunter C., Schettler G., Wulf S., Zolitschka B., and Negendank J. F. W. (2000) Abrupt environmental oscillations during the Early Weichselian recorded at Lago Grande di Monticchio, southern Italy. Quatern. Int. 73/74, 79-90.

Calanchi N., Cattaneo A., Dinelli E., Gasparotto G., and Lucchini F. (1998) Tephra layers in Late Quaternary sediments of the central Adriatic Sea. Mar. Geol., 149(1-4), 191-209.

Calanchi, N, Dinelli, E. (2008) Tephrostratigraphy of the last 170 ka in sedimentary successions from the Adriatic Sea. J. Volcan. Geoth. Res., 177 (1), 81-95.

Caron, B., Sulpizio, R., Zanchetta, G., Siani, G. and Santacroce, R. (2010) The Late Holocene to Pleistocene tephrostratigraphic record of Lake Ohrid (Albania). C. R. Geosci., 342 (96), 453-466.

Cioni R., D'Oriano, C., Bertagnini A. (2008). Fingerprinting ash deposits of small scale eruptions by their physical and textural features. J. Volcan. Geoth. Res. 177, 277-287

Civetta L., Orsi G., Pappalardo L., Fisher R. V., Heiken G., and Ort M. (1997) Geochemical zoning, mingling, eruptive dynamics and depositional processes - The Campanian Ignimbrite, Campi Flegrei caldera, Italy. J. Volcan. Geoth. Res., 75(3-4), 183-219.

Cornell W., S. Carey S., and Sigurdsson H. (1983) Computer simulation of transport and deposition of Campanian Y-5 ash. J. Volcan. Geoth. Res., 17, 89-109.

Costa A., Dell'Erba F., Di Vito M., Isaia R., Macedonio G., Orsi G., Pfeiffer T. (2009) Tephra fallout hazard assessment at the Campi Flegrei caldera (Italy) B. Volcan., 71, 259-273

Costa, A., Folch, A., Macedonio, G., Giaccio,, B., Isaia, R., Smith, V.C. (2012) 
1094

1095

1096

1097

1098

1099

1100

1101

1102

1103

1104

1105

1106

1107

1108

1109

1110

1111

1112

1113

1114

1115

1116

1117

1118

1119

1120

1121

1122

1123

1124

1125

1126

1127

1128

1129

1130

1131

1132

1133

1134

1135

1136

1137

1138
Quantifying volcanic ash dispersal and impact of the Campanian Ignimbrite super-eruption, Geophys. Res. Lett., 39 doi:10.1029/2012GL051605.

D'Antonio M., Tonarini S., Arienzo I., Civetta L., and Di Renzo V. (2007) Components and processes in the magma genesis of the Phlegraean Volcanic District, Southern Italy. In Cenozoic volcanism in the Mediterranean area, Vol. 418 (ed. L. Beccaluva, G. Bianchini, and M. wilson), pp. 203-220. Geological Society of America Special Publication.

De Vivo B., Rolandi G., Gans P. B., Calvert A., Bohrson W. A., Spera F. J., and Belkin H. E. (2001) New constraints on the pyroclastic eruptive history of the Campanian volcanic Plain (Italy). Miner. Petrol., 73(1-3), 47-65.

Deino A. L., Orsi G., de Vita S., and Piochi M. (2004) The age of the Neapolitan Yellow Tuff caldera-forming eruption (Campi Flegrei caldera Italy) assessed by Ar-40/Ar-39 dating method. J. Volcan. Geoth. Res., 133(1-4), 157-170.

Di Renzo V., Arienzo I., Civetta L., D'Antonio M., Tonarini S., Di Vito M. A., and Orsi G. (2011) The magmatic feeding system of the Campi Flegrei caldera: Architecture and temporal evolution. Chem. Geol. 281(3-4), 227-241.

Di Renzo V., Di Vito M. A., Arienzo I., Carandente A., Civetta L., D'Antonio M., Giordano F., Orsi G., and Tonarini S. (2007) Magmatic history of SommaVesuvius on the basis of new geochemical and isotopic data from a deep borehole (Camaldoli della Torre). J. Petrol., 48(4), 753-784.

Di Vito M. A., Isaia R., Orsi G., Southon J., de Vita S., D'Antonio M., Pappalardo L., and Piochi M. (1999) Volcanism and deformation since 12,000 years at the Campi Flegrei caldera (Italy). J. Volcan. Geoth. Res., 91(2-4), 221-246.

Di Vito M. A., Sulpizio R., Zanchetta G., and D'Orazio M. (2008) The late Pleistocene pyroclastic deposits of the Campanian Plain: new insights into the The late Pleistocene pyroclastic deposits of the Campanian Plain: new insights into the explosive activity of Neapolitan volcanoes. J. Volcan. Geoth. Res., 177(1), 19-48.

De Vivo B., Rolandi G., Gans P.B., Calvert A., Bohrson W.A., Spera F.J. and Belkin H.E. (2001) New constraints on the pyroclastic eruptive history of the Campanian volcanic Plain (Italy). In: De Vivo B, Rolandi G (eds) Mt Somma Vesuvius and Volcanism of the Campania Plain. Spec Issue Mineral Petrol 73:47-65.

D'Oriano C., Poggianti E., Bertagnini A., Cioni R., Landi P., Polacci M., and Rosi M. (2005) Changes in eruptive style during the A.D. 1538 Monte Nuovo eruption (Phlegrean Fields, Italy): the role of syn-eruptive crystallisation. $B$. Volcan., 67, 601-621.

Fedele F. G., Giaccio B., Isaia R., and Orsi G. (2003) The Campanian Ignimbrite eruption, Heinrich Event 4, and Palaeolithic change in Europe: a highresolution investigation. AGU Geophys. Monogr. 139, 301-327.

Fedele F. G., Giaccio B., Isaia R., Orsi G., Carroll M., and Scaillet B. (2007) The Campanian Ignimbrite Factor: Towards a Reappraisal of the Middle to Upper Palaeolithic "Transition". In Living Under the Shadow: The Cultural Impacts of Volcanic Eruptions (ed. J. G. a. R.Torrence), pp. 19-41. Left Coast Press. 
1139 Fedele L., Scarpati C., Lanphere M., Melluso L., Morra V., Perrotta A., and Ricci 
1184

1185

1186

1187

1188

1189

1190

1191

1192

1193

1194

1195

1196

1197

1198

1199

1200

1201

1202

1203

1204

1205

1206

1207

1208

1209

1210

1211

1212

1213

1214

1215

1216

1217

1218

1219

1220

1221

1222

1223

1224

1225

1226

1227

1228

1229

Morley, M.W. and Woodward, J.C. (in press) The Campanian Ignimbrite (Y5) tephra at CrvenaStijena Rockshelter, Montenegro. Quaternary Research.

Müller W., Shelley M., Miller P., and Broude S. (2009) Initial performance metrics of a new custom-designed ArF excimer LA-ICPMS system coupled to a two-volume laser-ablation cell. J. Anal. Atom. Spectrom., 24(2), 209-214.

Munno R. and Petrosino P. (2004) New constraints on the occurrence of the Y-3 upper Pliestocene tephra marker layer in the Tyrrhenian Sea. I/ Quaternario 17(1), 11-20.

Narcisi B. (1996) Tephrochronology of a late quaternary lacustrine record from the Monticchio maar (Vulture volcano, Southern Italy). Quaternary Sci. Rev., 15(2-3), 155-165.

Orsi G., Civetta L., D' Antonio M., Di Girolamo P., and Piochi M. (1995) StepFilling and Development of a 3-Layer Magma Chamber - the NeapolitanYellow-Tuff Case-History. J. Volcan. Geoth. Res., 67(4), 291-312.

Orsi G., Civetta L., Del Gaudio C., de Vita S., Di Vito M. A., Isaia R., Petrazzuoli S., Ricciardi G., and Ricco C. (1999a) Short-Term Ground Deformations and Seismicity in the Nested Campi Flegrei Caldera (Italy): an example of active block resurgence in a densely populated area. J. Volcan. Geoth. Res., 91, 415-451.

Orsi G., D' Antonio M., de Vita S., and Gallo G. (1992) The Neapolitan Yellow Tuff, a Large-Magnitude Trachytic PhreatoPlinian Eruption - Eruptive Dynamics, Magma Withdrawal and Caldera Collapse. J. Volcan. Geoth. Res., 53(1-4), 275-287.

Orsi G., de Vita S., Di Vito M. A., Isaia R., Nave R., and Heiken G. (2003) Facing volcanic and related hazards in the Neapolitan area. In Earth Sciences in the Cities: A Reader, Vol. 56 (ed. Heiken G., Fakundiny R., and Sutter J.), pp. 121-170. Am. Geophys. Un., Sp. Publ. Series.

Orsi G., de Vita S., and Di Vito M. A. (1996) The restless, resurgent Campi Flegrei nested caldera (Italy): Constraints on its evolution and configuration. $J$. Volcan. Geoth. Res., 74(3-4), 179-214.

Orsi G., Di Vito M. A., and Isaia R. (2004) Volcanic hazard assessment at the restless Campi Flegrei caldera. B. Volcanol., 66(6), 514-530.

Orsi G., Petrazzuoli S., and Wohletz K. (1999b) Mechanical and thermo-fluid behaviour during unrest episode at the Campi Flegrei caldera (Italy). J. Volcan. Geoth. Res., 91, 453-470.

Orsi G., Di Vito M.A., Selva J. and Marzocchi W. (2009) Long term forcast of eruption style and size at Campi Flegrei caldera (Italy). E Planet Sci Let 287, 265-276

Ort M., Orsi G., Pappalardo L., and Fisher R. (2003) Anisotropy of magnetic susceptibility studies of depositional processes in the Campanian Ignimbrite, Italy. B. Volcanol., 65(1), 55-72.

Pabst S., Worner G., Civetta L., and Tesoro R. (2008) Magma chamber evolution prior to the Campanian Ignimbrite and Neapolitan Yellow Tuff eruptions (Campi Flegrei, Italy). B. Volcanol., 70(8), 961-976.

Pappalardo L., Civetta L., D'Antonio M., Deino A., Di Vito M.A., Orsi G., Carandente A., de Vita S., Isaia R., and Piochi M. (1999) Chemical and Sr- 
isotopical evolution of the Phlegraean magmatic system before the Campanian Ignimbrite and the Neapolitan Yellow Tuff eruptions. J. Volcan. Geoth. Res., 91(2-4), 141-166.

Pappalardo L., Civetta L., de Vita S., Di Vito M. A., Orsi G., Carandente A., and Fisher R. V. (2002a) Timing of magma extraction during the Campanian Ignimbrite eruption (Campi Flegrei Caldera). J. Volcan. Geoth. Res., 114(34), 479-497.

Pappalardo L., Ottolini L., and Mastrolorenzo G. (2008) The Campanian Ignimbrite (southern Italy) geochemical zoning: insight on the generation of a supereruption from catastrophic differentiation and fast withdrawal. Contrib. Mineral. and Petr., 156(1), 1-26.

Pappalardo L., Piochi M., D'Antonio M., Civetta L., and Petrini R. (2002b) Evidence for multi-stage magmatic evolution during the past $60 \mathrm{kyr}$ at Campi Flegrei (Italy) deduced from $\mathrm{Sr}, \mathrm{Nd}$ and $\mathrm{Pb}$ isotope data. J. Petrol., 43(8), 1415-1434.

Paterne M., Guichard F., and Labeyrie J. (1988) Explosive activity of the South Italian volcanoes during the past 80,000 years as determined by marine tephrochronology. J. Volcan. Geoth. Res., 34(3-4), 153-172.

Paterne M., Guichard F., and Labeyrie J. (1988) Explosive activity of the South Italian volcanoes during the past 80,000 years as determined by marine tephrochronology. J. Volcan. Geoth. Res., 34(3-4), 153-172.

Perrotta A. and Scarpati C. (2003) Volume partition between the Plinian and coignimbrite air fall deposits of the Campanian Ignimbrite eruption. Miner Petrol., 79, 67-78.

Polacci M., Pioli L., and Rosi M. (2003) The Plinian phase of the Campanian Ignimbrite eruption (Phlegrean Fields, Italy): evidence from density measurements and textural characterization of pumice. B. Volcanol., 65(6), 418-432.

Pyle D. M., Ricketts G. D., Margari V., van Andel T. H., Sinitsyn A. A., Praslov N. D., and Lisitsyn S. (2006) Wide dispersal and deposition of distal tephra during the Pleistocene 'Campanian Ignimbrite/Y5' eruption, Italy. Quaternary Sci. Rev., 25(21-22), 2713-2728.

Reimer P. J., Baillie M. G. L., Bard E., Bayliss A., Beck J. W., Blackwell P. G., Bronk Ramsey C., Buck C. E., Burr G. S., Edwards R. L., Friedrich M., Grootes P. M., Guiderson T. P., Hajdas I., Heaton T. J., Hogg A. G., Hughen K. A., Kaiser K. F., Kromer B., McCormac F. G., Manning S. W., Richards D. A., Southon J. R., Talamo S., Turney C. S. M., van der Plicht J., and Weyhenmeyer C. E. (2009) IntCal09 and Marine09 radiocarbon age calibration curves, 0-50,000 years cal BP. Radiocarbon 51(4), 1111-1150.

Rittmann A. (1950) Sintesi geologica dei Campi Flegrei. Boll. Soc. Geol. Ital. 69, 117-177.

Rolandi G., Bellucci F., Heizler M. T., Belkin H. E., and De Vivo B. (2003) Tectonic controls on the genesis of ignimbrites from the Campanian Volcanic Zone, southern Italy. Miner. Petrol., Vol. 79, pp. 3-31. 
1274 Rosi M., Vezzoli L., Castelmenzano A., and Grieco G. (1999) Plinian pumice fall

1275

1276

1277

1278

1279

1280

1281

1282

1283

1284

1285

1286

1287

1288

1289

1290

1291

1292

1293

1294

1295

1296

1297

1298

1299

1300

1301

1302

1303

1304

1305

1306

1307

1308

1309

1310

1311

1312

1313

1314

1315

1316

1317

1318

1319 deposit of the Campanian Ignimbrite eruption (Phlegraean Fields, Italy). Journal of Volcanology and Geothermal Research 91(2-4), 179-198.

Santacroce R., Cristofolini R., La Volpe, L., Orsi G., and Rosi M. (2003) Italian Active Volcanoes. Episodes 26(3), 227-234.

Schmidt R., van den Bogaard C., Merkt J., and Müller J. (2002) A new Lateglacial chronostratigraphic tephra marker for the south-eastern Alps: The Neapolitan Yellow Tuff (NYT) in Längsee (Austria) in the context of a regional biostratigraphy and palaeoclimate. Quatern. Int., 88(1), 45-56.

Selva J., Orsi G., Di Vito M.A., Marzocchi W. and Sandri L. (2012) Probability hazard map for future vent opening at the Campi Flegrei caldera, Italy. $B$. Volcan., 74, 497-510

Seymour, St K., Christanis, K., Bouzinos, A., Papazisimou, S., Papatheodorou, G., Moran, E. and Denes, G., 2004. Tephrostratigraphy and tephrochronology in the Philippi peat basin, Macedonia, Northern Hellas (Greece). Quatern. Int., 121, 53-65.

Siani G., Sulpizio R., Paterne M., and Sbrana A. (2004) Tephrostratigraphy study for the last 18,000 C-14 years in a deep-sea sediment sequence for the South Adriatic. Quaternary Science Reviews 23(23-24), 2485-2500.

Smith V. C., Isaia R., and Pearce N. J. (2011) Tephrostratigraphy and glass compositions of post-15 kyr Campi Flegrei eruptions: implications for eruption history and chronostratigraphic markers. Quaternary Sci. Rev. 30(25-26), 638-3660.

Sparks R. S. J. and T.C. H. (1980) The volcanological significance of deep-sea ash layers associated with ignimbrites. Geol. Mag. 117, 425-436.

Sulpizio R. (2005). Three empirical methods for the calculation of distal volume of tephra-fall deposits. J. Volcan. Geoth. Res., 145(3-4), 315-336.

Sulpizio R., Zanchetta G., D'Orazio M., Vogel H., Wagner B. (2010) Tephrostratigraphy and tephrochronology of lakes Ohrid and Prespa, Balkans. Biogeosciences, 7, 3273-3288.

Sulpizio R., van Welden A., Caron B., Zanchetta G. (2010) The Holocene tephrostratigraphic record of Lake Shkodra (Albania and Montenegro). J. Quaternary Sci., 25, 633-650.

Sun S.-S. and McDonough W. F. (1989) Chemical and isotopic systematics of oceanic basalts: implications for mantle composition and processes. In Magmatism in Ocean Basins, Vol. 42 (ed. A. D. Saunders, Norry, M.J.), pp. 313-345. Geological Society of London Special Publication.

Thirlwall M. F. (1991) Long-Term Reproducibility of Multicollector Sr and $\mathrm{Nd}$ Isotope Ratio Analysis. Chem. Geol. 94(2), 85-104.

Thunell R., Federman A., Sparks S., and Williams D. (1979) The age, origin, and volcanological significance of the Y-5 ash layer in the Mediterranean. Quaternary Research 12(2), 241-253.

Tomlinson E. L., Thordarson T., Muller W., Thirlwall M., and Menzies M. A. (2010) Micro analysis of tephra by LA-ICP-MS - strategies, advantages and limitations assessed using the Thorsmork ignimbrite (Southern Iceland). Chem. Geol. 279(3-4), 73-89. 
1320

1321

1322

1323

1324

1325

1326

1327

1328

1329

1330

1331

1332

1333

1334

1335

1336

1337

1338

1339

1340

1341

1342

1343

1344

1345

1346

1347

1348

1349

1350

1351

1352

1353

1354

1355

1356

1357

1358

1359

1360

1361

1362

1363

1364

1365

Tonarini S., Leeman W. P., Civetta L., D'Antonio M., Ferrara G., and Necco A. (2004) B/Nb and systematics in the Phlegrean Volcanic District (PVD). J. Volcan. Geoth. Res., 113, 123-139.

Ton-That T., Singer B., and Paterne M. (2001) 40Ar/39Ar dating of latest Pleistocene (41 ka) marine tephra in the Mediterranean Sea: implications for global climate records. Earth Planet. Sci. Lett., 184(3-4), 645-658.

Veres, D., Lane, C.S., Timar-Gabor, A., hambach, U., Constantin, D., Szakács, A., Fülling, A. and Onac, B.P. (in press). The Campanian Ignimbrite/Y5 tephra layer - A regional stratigraphic marker for Isotope Stage 3 deposits in the Lower Danube region. Quatern. Int.

Vezzoli L. (1991) Tephra layers in Bannock Basin (Eastern Mediterranean). Mar. Geol., 100(1-4), 21-34.

Vogel H., Zanchetta G., Sulpizio R., Wagner B., Nowaczyk N. (2010). A tephrostratigraphic record for the last glacial-interglacial cycle from Lake Ohrid, Albania and Macedonia. J.Quaternary Sci., 25, 320-338.

Wagner B., Sulpizio R., Zanchetta G., Wulf S., Wessels M., Daut G., and Nowaczyk N. (2008) The last 40 ka tephrostratigraphic record of Lake Ohrid, Albania and Macedonia: a very distal archive for ash dispersal from Italian volcanoes. J. Volcan. Geoth. Res., 177(1), 71-80.

Wohletz K., Civetta L., and Orsi G. (1999) Thermal evolution of the Phlegraean magmatic system. J. Volcan. Geoth. Res., 91(2-4), 381-414.

Wohletz K., Orsi G., and de Vita S. (1995) Eruptive Mechanisms of the Neapolitan Yellow Tuff Interpreted from Stratigraphic, Chemical, and Granulometric Data. J. Volcan. Geoth. Res., 67, 263-290.

Wulf S., Brauer A., Mingram J., Zolitschka B., and Negendank J. F. W. (2007) Distal tephras in the sediments of Monticchio maar lakes. In Geologia del Monte Vulture (ed. C. Principe), pp. 105-122.

Wulf S., Kraml M., Brauer A., Keller J., and Negendank J. F. W. (2004) Tephrochronology of the 100 ka lacustrine sediment record of Lago Grande di Monticchio (southern Italy). Quatern. Int., 122, 7-30.

Wulf S., Kraml M., and Keller J. (2008) Towards a detailed distal tephrostratigraphy in the Central Mediterranean: The last 20,000 yrs record of Lago Grande di Monticchio. J. Volcan. Geoth. Res., 177(1), 118-132.

Zanchetta G., Di Vito M.A., Fallick A. E., and Sulpizio R. (2000) Stable isotopes of pedogenic carbonates from the Somma-Vesuvius area, Southern Italy, over the past $18 \mathrm{kyr}$ : paleoclimatic implications. J.Quaternary Sci., 15(8), 813824.

Zanchetta G., Sulpizio R., Giaccio B., Siani G., Paterne M., Wulf S., and D'Orazio M. (2008) The Y-3 tephra: A Last Glacial stratigraphic marker for the central Mediterranean basin. J. Volcan. Geoth. Res., 177(1), 145-154.

Zollo A., Maercklin N., Vassallo M., Dello lacono D., Virieux J., and Gasparini P. (2008) Seismic reflections reveal a massive melt layer under Campi Flegrei volcanic field. Geophys. Res. Lett., 244(35), L12306.

\section{CAPTIONS}




\section{Tables}

Table 1: Summary of Phlegraean Fields eruptions and samples studied. Samples used in previous studies 1 - Tortora unpublished MSc thesis; 2 - Pappalardo et al. (1999); 3 - Arienzo et al. (2009), resampled 10/2008; 4 - Polacci et al. (2003). Ages are from: PP - Smith et al. (2011), NYT- De Vivo et al. (2001), Cl - Deino et al. (2004) PRa, VRb and TLa - Pappalardo et al. (1999). Mineral abbreviations: san - sanidine, plg - plagioclase, cpx - clinopyroxene, bt - biotite, mag magnetite, ap - apatite, ol - olivine.

Table 2: Representative EMPA analyses of volcanic glass selected on basis of $\mathrm{CaO}\left(20^{\text {th }}, 40^{\text {th }}, 60^{\text {th }}, 80^{\text {th }}\right.$ percentile for most samples, $33^{\text {th }}$ and $66^{\text {th }}$ percentiles for each mode of bimodal units) and ordered by increasing $\mathrm{CaO}$. Major element totals are normalised to $100 \mathrm{wt} \%$, the pre-normalised total is also given. a) PP, NYT and Pre-NYT eruptions; b) $\mathrm{Cl}$ and Pre-Cl eruptions. The full dataset is given as online supplementary data.

Table 3: Representative LA-ICP-MS analyses of volcanic glass selected on basis of $\operatorname{Sr}\left(20^{\text {th }}, 40^{\text {th }}, 60^{\text {th }}, 80^{\text {th }}\right.$ percentile for most samples, $33^{\text {th }}$ and $66^{\text {th }}$ percentiles for each mode of bimodal units): a) PP, NYT and Pre-NYT eruptions; b) $\mathrm{Cl}$ and Pre- $\mathrm{Cl}$ eruptions. The full dataset is given as online supplementary data.

Table 4: Representative major (EMPA) and trace (LA-ICP-MS) element composition of glass shards from Lago Grande di Monticcio tephra units.

Table 5: Key concentrations and ratios for geochemical fingerprinting. ${ }^{*}$ Total Alkali $\left(\mathrm{Na}_{2} \mathrm{O}+\mathrm{K}_{2} \mathrm{O}\right)$ versus Silica $\left(\mathrm{SiO}_{2}\right)$ (Le Bas and Streckeisen, 1991).

Table 6: Summary of information relevant to proximal-medial-distal correlations. Ages have been calibrated using the IntCal09 or Marine09 internationally accepted calibration curves (Reimer et al., 2009) at $2 \sigma$. Year 0 is 1950 AD. Please see references for uncalibrated radiocarbon determinations. Distal tephra occurrences are those supported by this study, in the case of the $\mathrm{Cl}$ only studies with trace element data are listed.

\section{Figures}

Figure 1: a) regional map of study area, inset shows location of: b) Map of field localities modified after Orsi et al. (2003).

Figure 2: Total alkali-silica plot (Le Bas and Streckeisen, 1991) showing the Clseries (red/orange), NYT-series (blues) and PP (green). Also shown are distal tephra layers from the Lago Grande di Monticchio core (black). Errors are 2 s.d. calculated using replicate analyses of MPI-DING StHs6/80 glass. 
1411 Figure 3: Major element biplots showing normalised compositions of glasses from 1412 the Cl-series (red/orange), NYT-series (blues) and PP (green). Also shown are 1413 distal tephra layers from the Lago Grande di Monticchio core (black). Errors are 2 1414 1415 1416 1417 1418 1419 1420 1421 1422 1423 1424 1425

1429 Figure 7: Trace element compositions of Lago Grande di Monticchio tephras 1430 normalised to the average composition (grey field) and compared to 1431 representative proximal compositions $\left(10^{\text {th }}, 20^{\text {th }}, 30^{\text {th }}, 40^{\text {th }}, 50^{\text {th }}, 60^{\text {th }}, 70^{\text {th }}, 80^{\text {th }}\right.$, $143290^{\text {th }}$ Sr percentile where $>20$ analyses): a) TM-7b and PP; b) TM-8 and NYT-UM; 1433 c) TM-8 and NYT-LM; d) TM15 and VRa; e) TM-18 base and Cl fall; f) TM-18 top 1434 and $\mathrm{Cl}$ flow - lower/intermediate flow.

Figure 8: Example biplots for assessing proximal distal tephra correlations: a) P/TM-7b, MgO-SiO ${ }_{2}$; b) NYT/TM-8 CaO-SiO ; c) GM1/TM-9 $\mathrm{K}_{2} \mathrm{O}-\mathrm{SiO}_{2}$; d) GM1/TM-9 MgO-SiO 2 ; e) VRa/TM15/Y3 Na $\mathrm{N}_{2}-\mathrm{SiO}_{2}$; f) VRa/TM15/Y3 FeO-SiO 1439 Proximal samples (PP in green, NYT-series in blue) and Lago Grande di 1440 Monticchio (black) symbols are as in other plots. Distal marine locations are 1441 shown in red, lake settings in orange. 


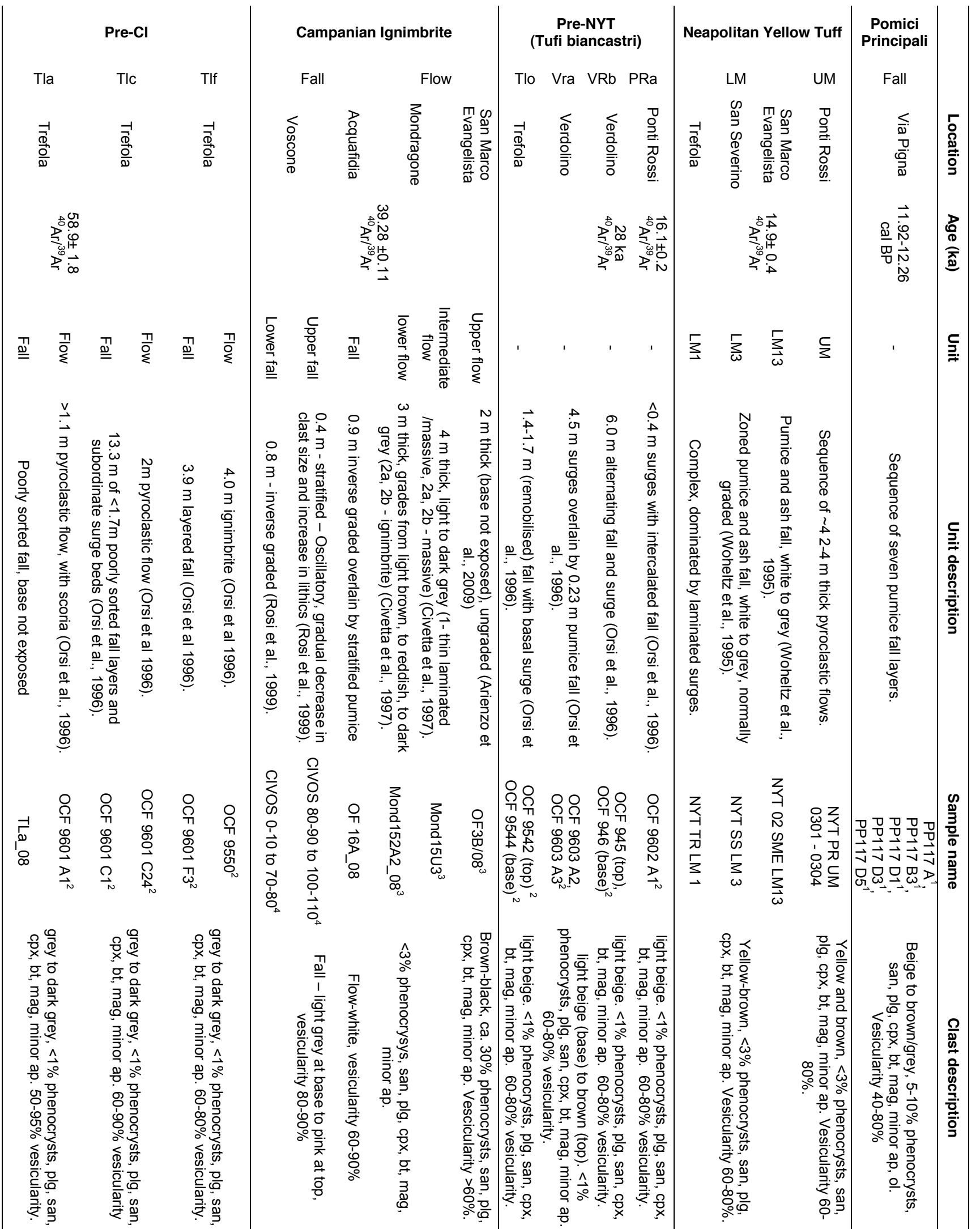




\begin{tabular}{|c|c|c|}
\hline 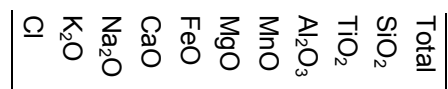 & sample & 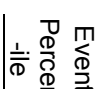 \\
\hline 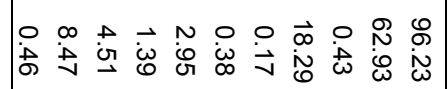 & OF3B/08-30 & N \\
\hline 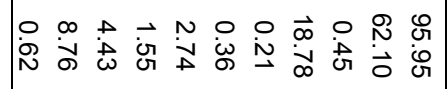 & OF3B/08-7 & D $\frac{\varrho}{\frac{c}{0}}$ \\
\hline 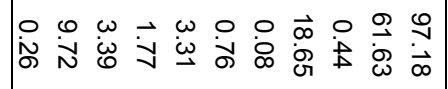 & OF3B/08-20 & $8 \stackrel{\frac{0}{D}}{\bar{\partial}}$ \\
\hline 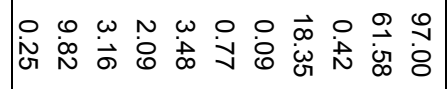 & OF3B/08-17 & $\stackrel{\infty}{\circ}$ \\
\hline 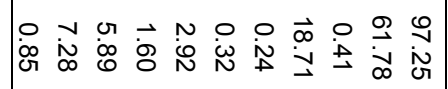 & MondOF15U3-13 & $\approx \frac{\varrho}{\bar{o}}$ \\
\hline 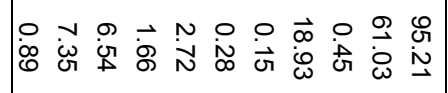 & $\begin{array}{l}\text { Mond152 A2_08- } \\
25\end{array}$ & 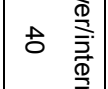 \\
\hline 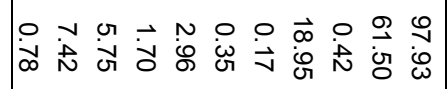 & MondOF 15U3-4 & 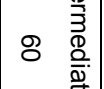 \\
\hline 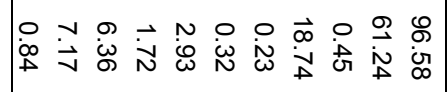 & $\begin{array}{l}\text { Mond152 A2_08- } \\
19\end{array}$ & 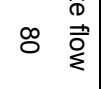 \\
\hline 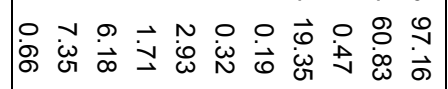 & CIVOS 100110-7 & N \\
\hline 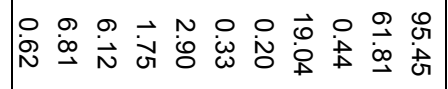 & 16A_08 -1 & $8 \cong$ \\
\hline 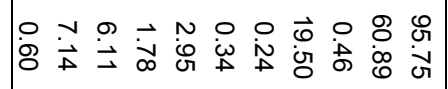 & CIVOS 60-70-22 & 8 \\
\hline 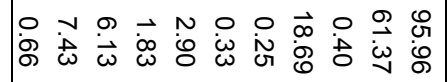 & 16A_08 -2 & $\stackrel{\infty}{\circ}$ \\
\hline 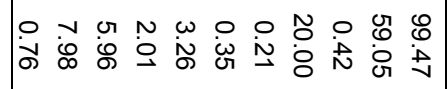 & OCF $9550-13$ & N \\
\hline 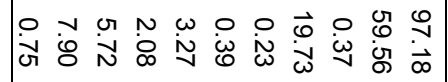 & OCF 9601 F3-12 & $\therefore \stackrel{0}{\phi}$ \\
\hline 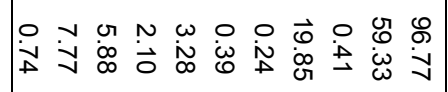 & OCF 9550-2 & $8 \frac{2}{7}$ \\
\hline 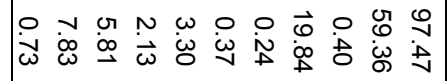 & OCF 9601 F3-9 & $\stackrel{\infty}{\circ}$ \\
\hline 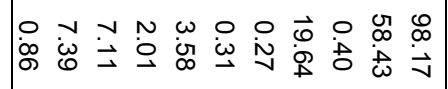 & OCF 9601 C24-6 & N \\
\hline 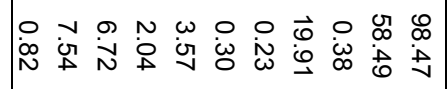 & OCF 9601 C24-2 & 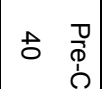 \\
\hline 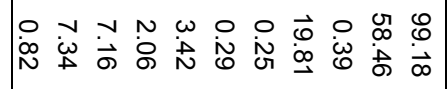 & OCF 9601 C1-13 & $8 \frac{2}{-1}$ \\
\hline 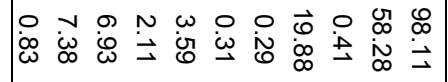 & OCF 9601 C24-11 & $\stackrel{\infty}{\circ}$ \\
\hline 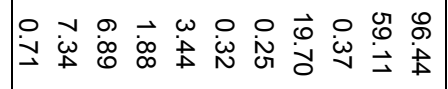 & OCF 9602 A1-8 & N \\
\hline 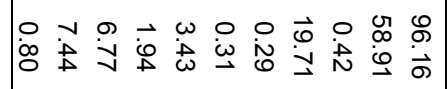 & OCF 9602 A1-4 & $\begin{array}{ll}0 \\
0 & \begin{array}{l}0 \\
\phi \\
\vdots\end{array} \\
0\end{array}$ \\
\hline 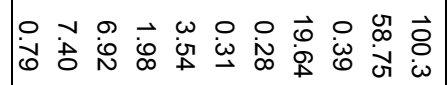 & OCF 9602 A1-10 & $8 \frac{-1}{0}$ \\
\hline 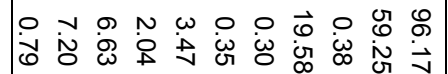 & Tla_08-6 & $\stackrel{\infty}{\circ}$ \\
\hline
\end{tabular}

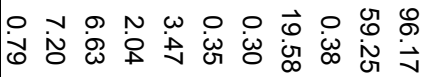

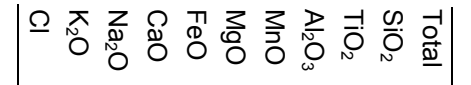

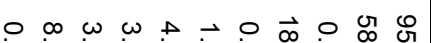
め $\&$ 엉

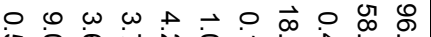
$\circlearrowleft$

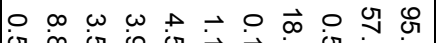

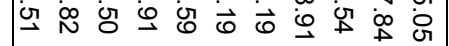

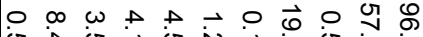

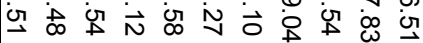
$\circ \infty+N N O P$ o $\circ \stackrel{\rightarrow}{\rightarrow}$

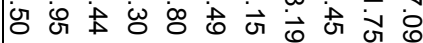

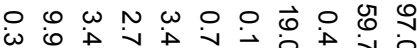

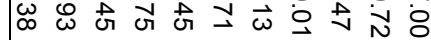

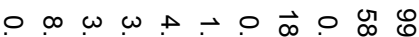

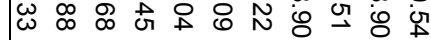

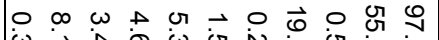
$\dot{\omega} \vec{\omega}$ मे $\circ \circ+N$ N O O

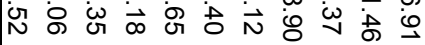

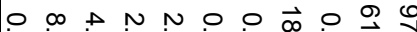

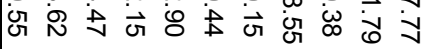

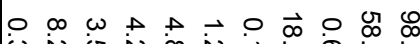

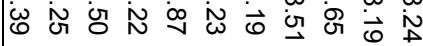

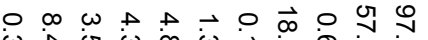

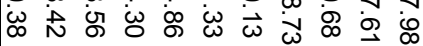
O मे O

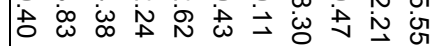
o $\infty$ N N

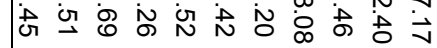
O $\rightarrow N N$ N

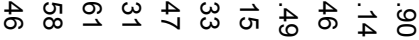

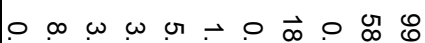

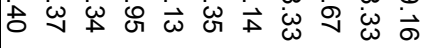

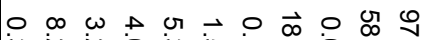

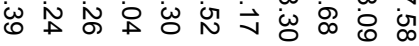
O D $+N$ N 0 O

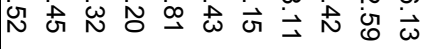

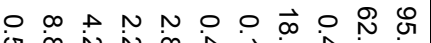

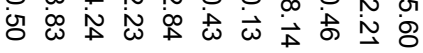
O 故 - + N N O O $\overrightarrow{0} \circ \mathbb{N}$ \%

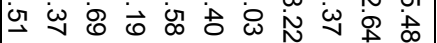
O

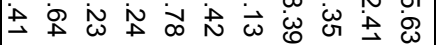

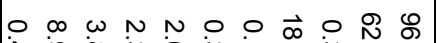

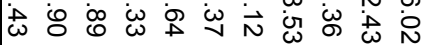

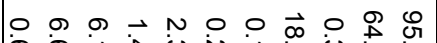

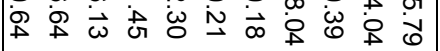

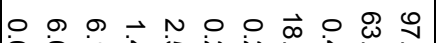

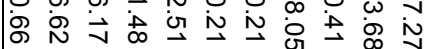

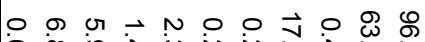

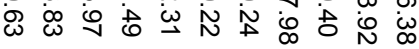

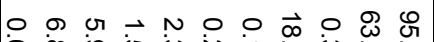

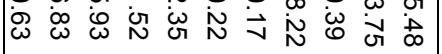

\begin{tabular}{|c|c|}
\hline sample & \\
\hline PP117 A-1 & \\
\hline PP117 A-13 & \\
\hline PP117 D3-2 & \\
\hline PP117 D5-27 & \\
\hline $\begin{array}{c}\text { NYT PR UM } \\
0301-3\end{array}$ & \\
\hline $\begin{array}{c}\text { NYT PR UM } \\
0301-2\end{array}$ & \\
\hline $\begin{array}{l}\text { NYT PR UM } \\
0302-2\end{array}$ & \\
\hline $\begin{array}{l}\text { NYT PR UM } \\
0304-17\end{array}$ & \\
\hline $\begin{array}{l}\text { NYT TR } \\
\text { LM1-1 }\end{array}$ & \\
\hline $\begin{array}{l}\text { NYT TR } \\
\text { LM1-7 }\end{array}$ & \\
\hline $\begin{array}{l}\text { NYT } 02 \text { SME } \\
\text { LM13-6 }\end{array}$ & \\
\hline $\begin{array}{l}\text { NYT } 02 \text { SME } \\
\text { LM13-1 }\end{array}$ & \\
\hline OCF 945-3 & \\
\hline OCF 946-1 & \\
\hline OCF $945-1$ & \\
\hline OCF 945-9 & \\
\hline 9603 A3-9 & \\
\hline 9603 АЗ-8 & \\
\hline 9603 A2-6 & \\
\hline 9603 A2-10 & \\
\hline $\begin{array}{l}\text { OCF9602 } \\
\text { A1-19 }\end{array}$ & \\
\hline $\begin{array}{l}\text { OCF9602 } \\
\text { A1-9 }\end{array}$ & \\
\hline $\begin{array}{l}\text { OCF9602 } \\
\text { A1-25 }\end{array}$ & \\
\hline $\begin{array}{l}\text { OCF9602 } \\
\text { A1-13 }\end{array}$ & \\
\hline OCF 9544-2 & \\
\hline OCF 9544-5 & 0 \\
\hline OCF 9542-5 & 0 \\
\hline JCF 9542-8 & \\
\hline
\end{tabular}





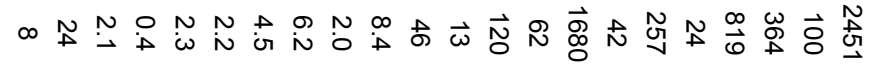

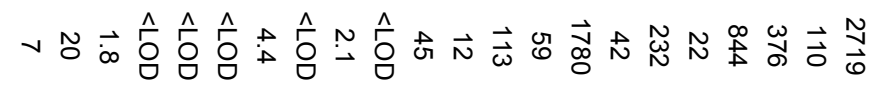

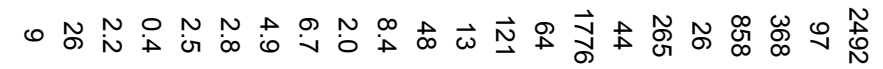

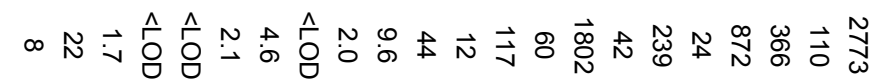

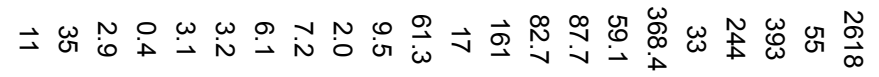

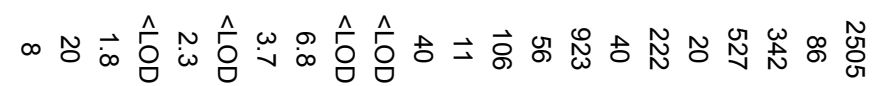

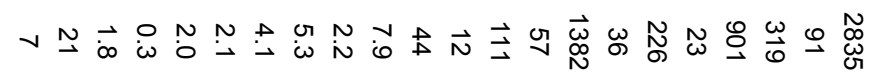

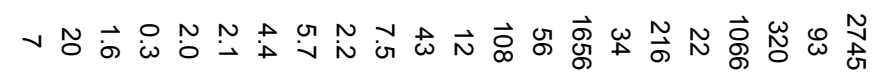

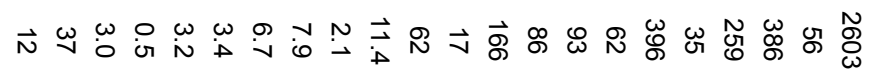

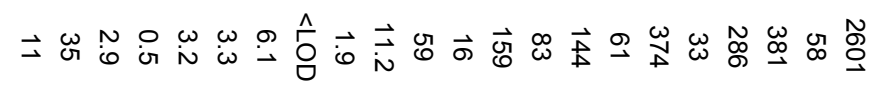

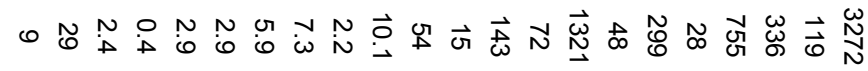

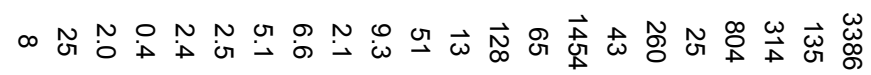

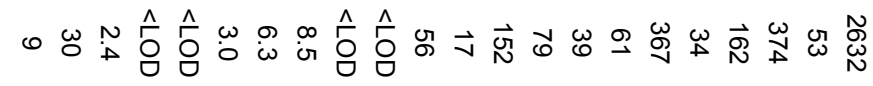

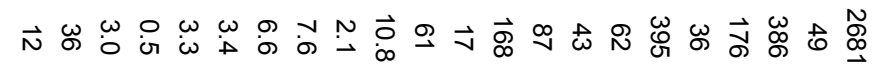

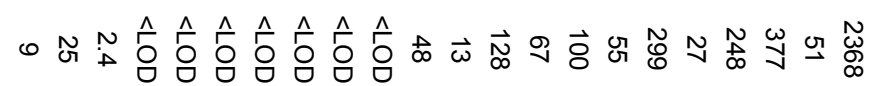

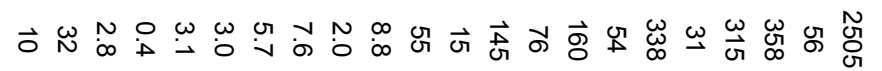

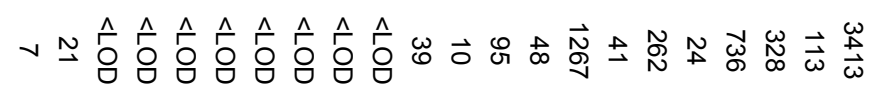

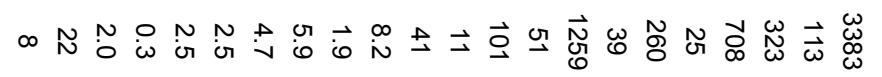

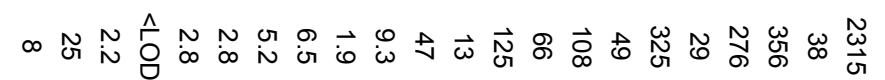

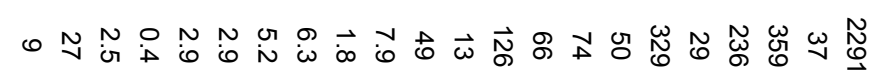

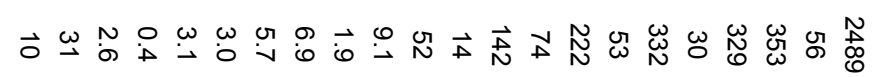

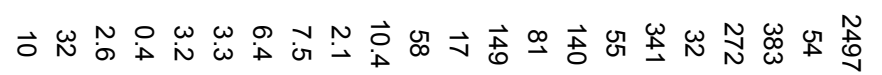

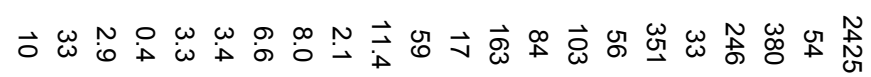

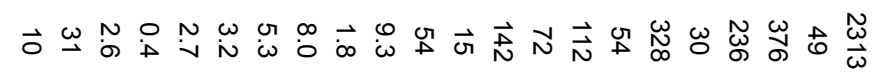

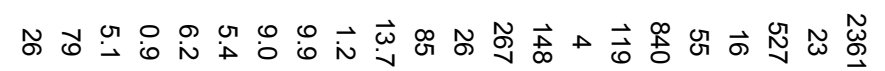

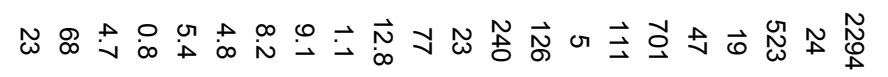

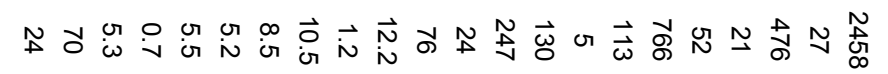

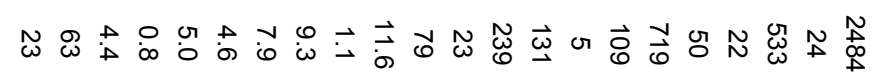

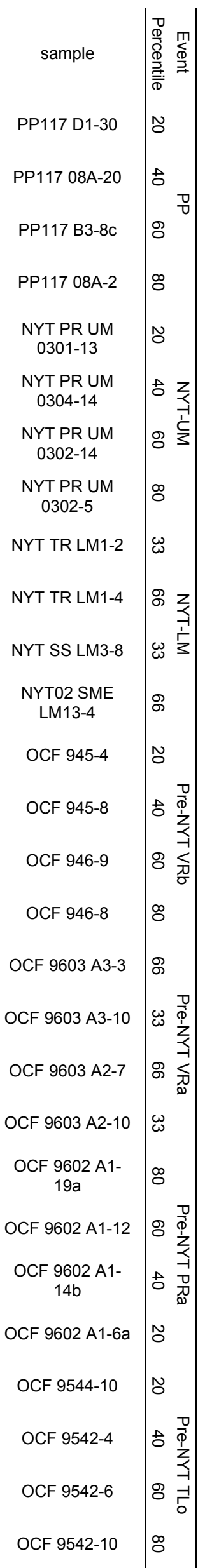




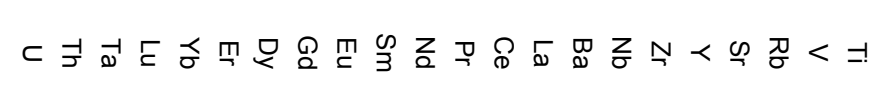

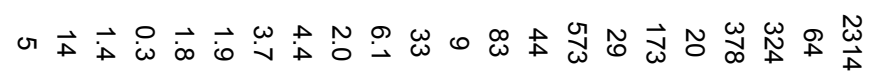

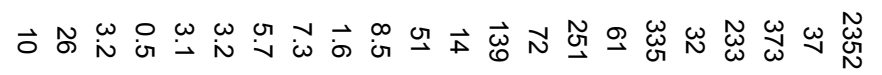

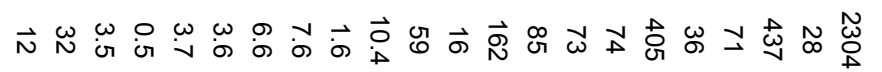

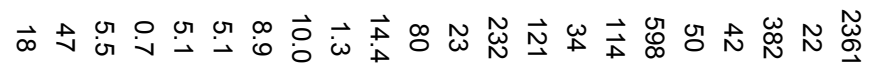

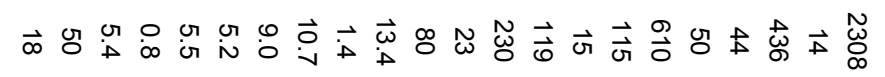

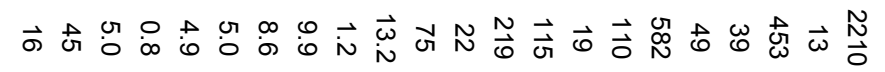

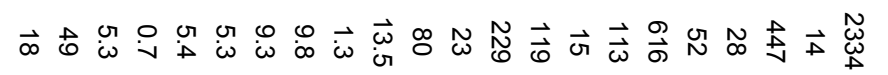

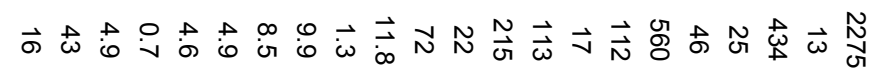
जे की

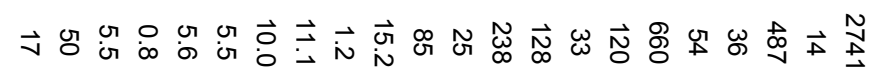

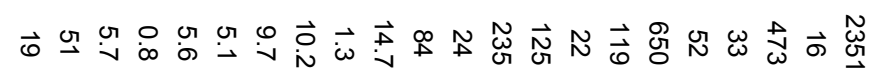

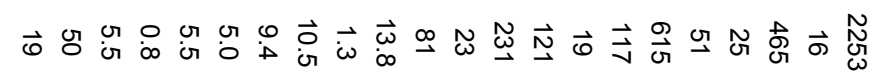

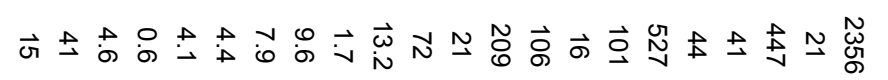

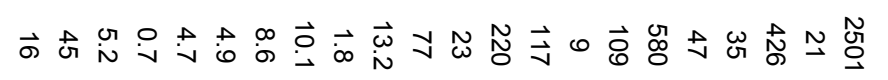

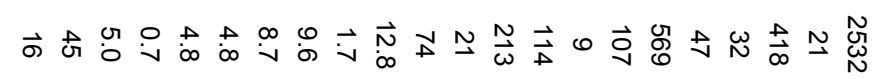

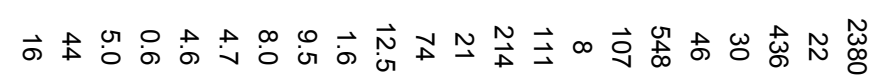

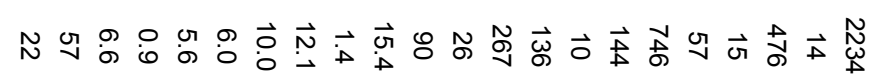

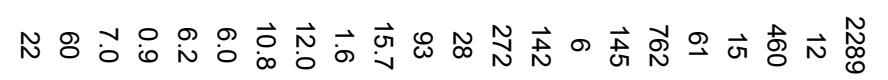

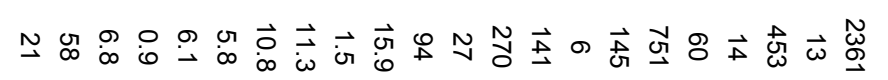

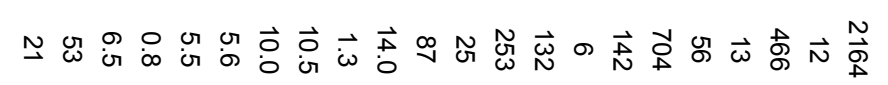

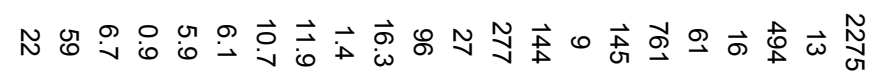

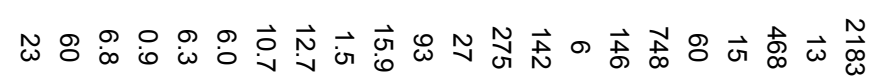

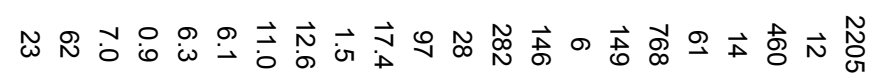

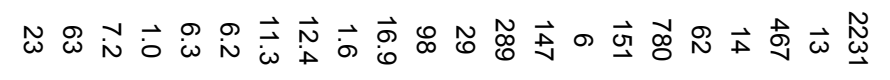

\begin{tabular}{|c|c|}
\hline Sample & 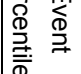 \\
\hline OF3B/08-20 & \\
\hline OF3B/08-19 & \\
\hline OF3B/08-10 & \\
\hline OF3B/08-6 & \\
\hline Mond152A2_08-4 & \\
\hline Mond15U3-8 & \\
\hline Mond15U3-11 & \\
\hline Mond15U3-2 & \\
\hline CIVOS 60-70-17 & \\
\hline OF 16A_08-10 & \\
\hline CIVOS 100-110-17 & $A$ \\
\hline CIVOS 100-110-27 & N \\
\hline OCF 9601 F3-15 & $\stackrel{\infty}{\circ}$ \\
\hline OCF 9601 F3-12 & \\
\hline OCF 9550-15 & \\
\hline OCF 9601 F3-13 & $\tilde{O}$ \\
\hline OCF 9601 C1-14 & $\varnothing^{\infty}$ \\
\hline OCF 9601 C24-11 & \\
\hline OCF 9601 C24-6 & \\
\hline OCF 9601 C24-15 & $\tilde{N}$ \\
\hline TLa_08-2 & 0 \\
\hline OCF 9601 A1-10 & \\
\hline OCF 9601 A1-7 & \\
\hline OCF 9601 A1-6 & \\
\hline
\end{tabular}




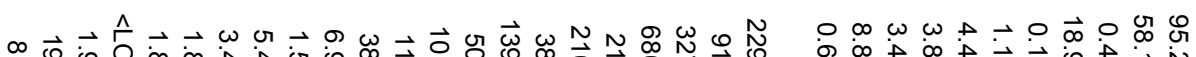

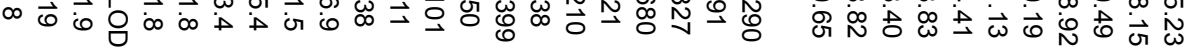

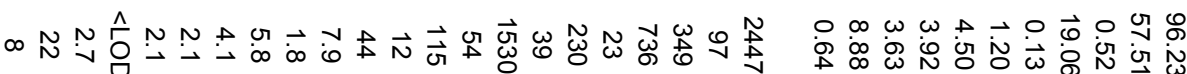

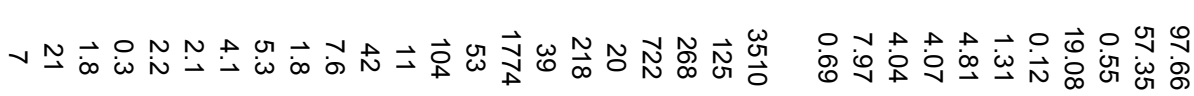

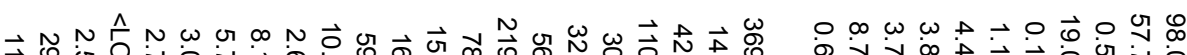
व ज व $\rightarrow \omega \omega \circ \omega \omega$ U

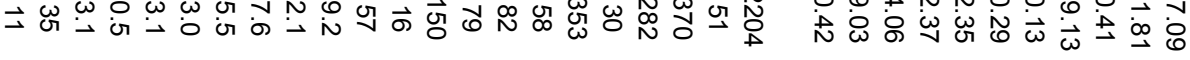

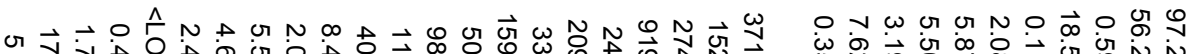

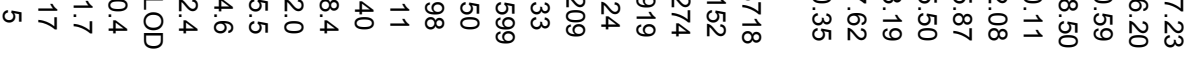

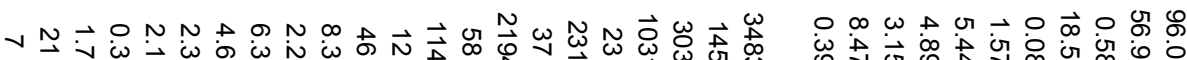
0 ज $V N \rightarrow O N N$ U 等

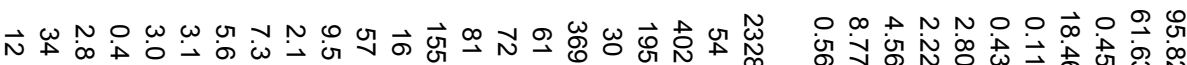

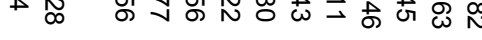

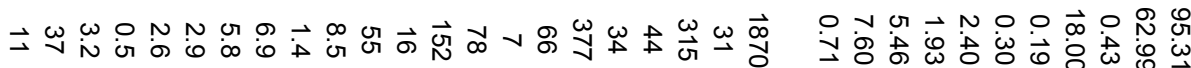

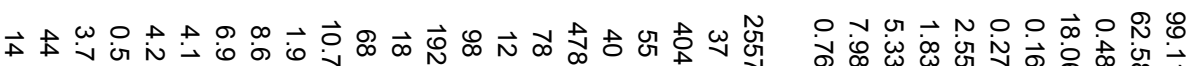

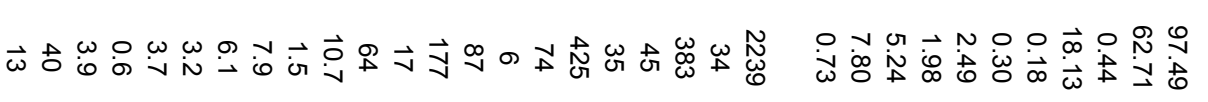

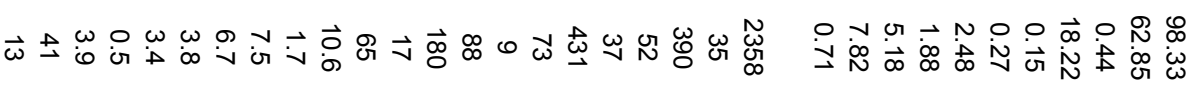

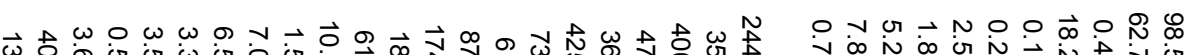

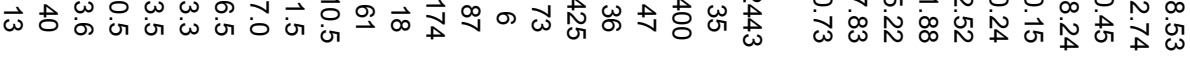

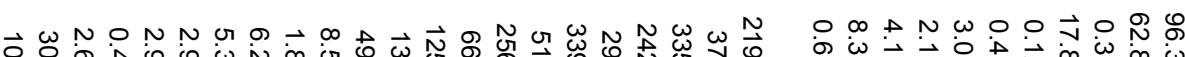

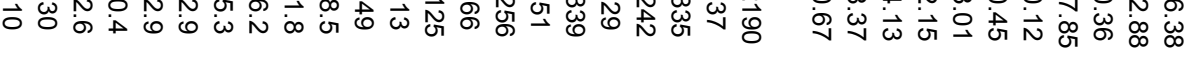

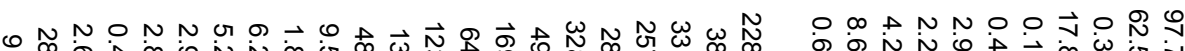

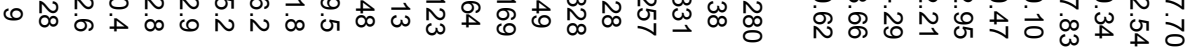

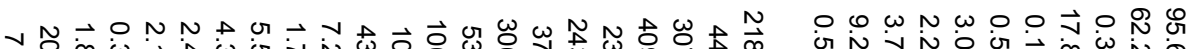

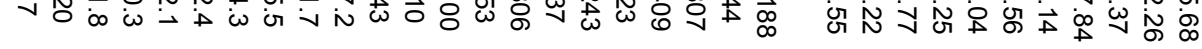

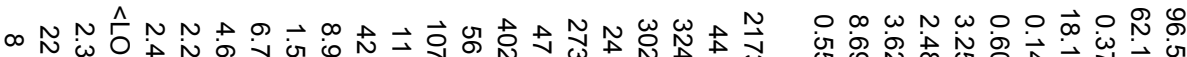

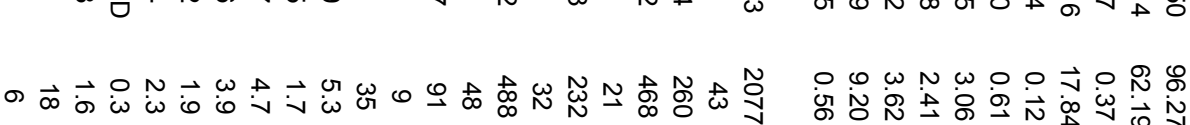




\begin{tabular}{|c|c|c|}
\hline 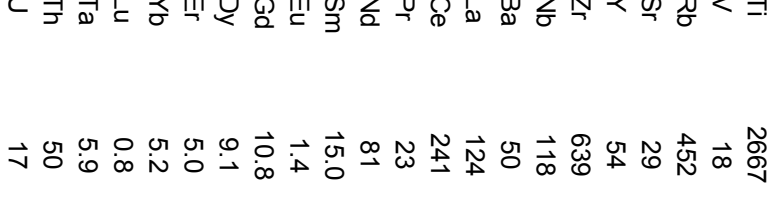 & 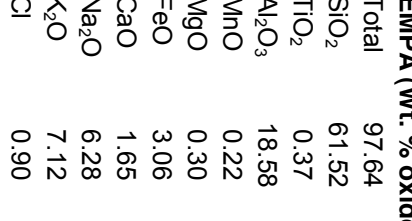 & \\
\hline 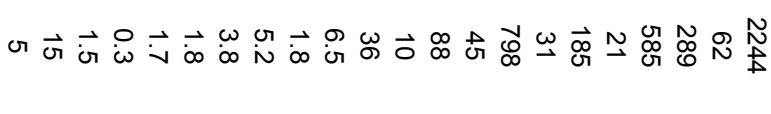 & 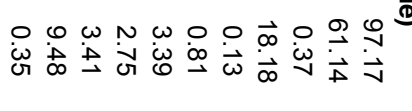 & 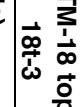 \\
\hline 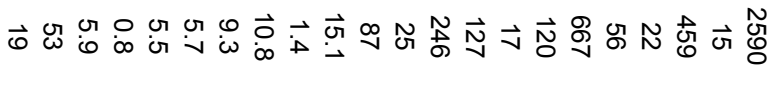 & 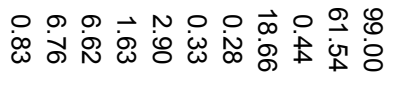 & \\
\hline 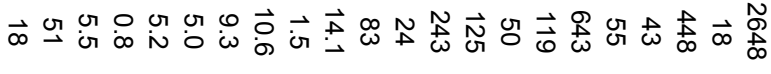 & 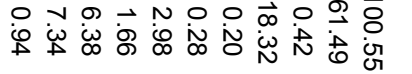 & \\
\hline 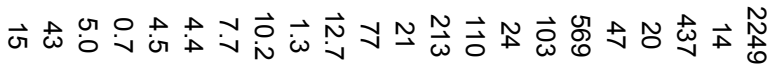 & 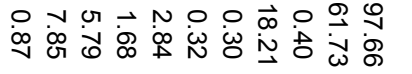 & $\mid \begin{array}{l}\mathbf{D} \\
\stackrel{p}{0} \\
\dot{\omega}\end{array}$ \\
\hline 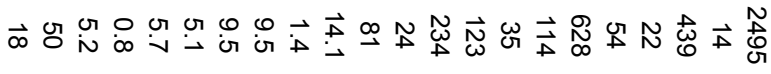 & 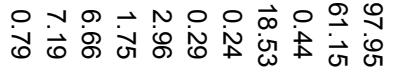 & $\vec{m}$ \\
\hline 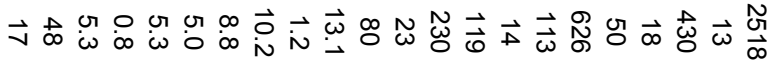 & 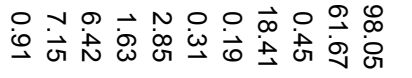 & \\
\hline 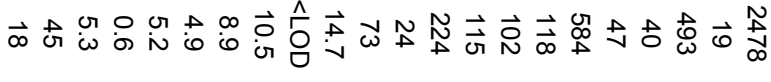 & 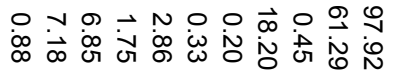 & \\
\hline 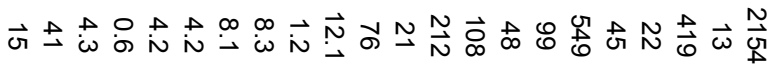 & 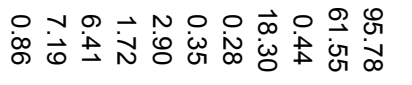 & \\
\hline 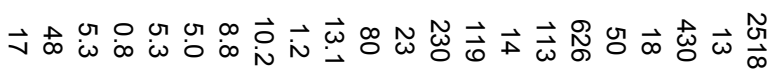 & 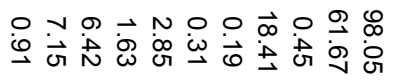 & 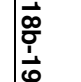 \\
\hline
\end{tabular}




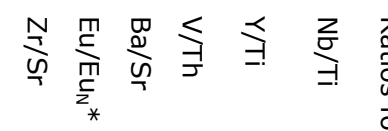

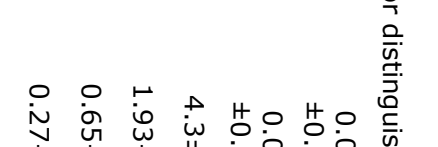

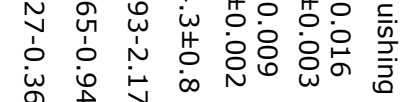

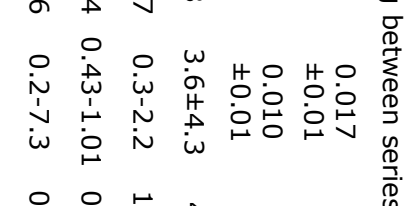

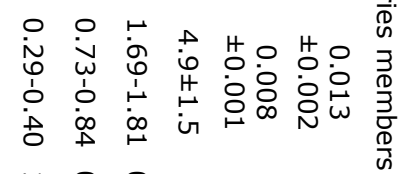

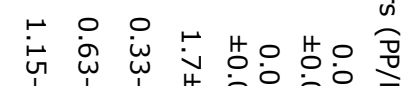

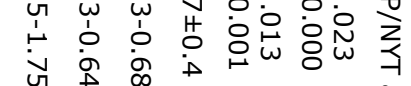

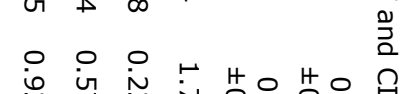

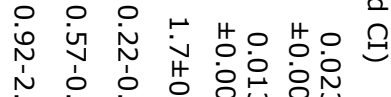

崩

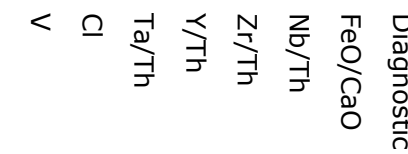

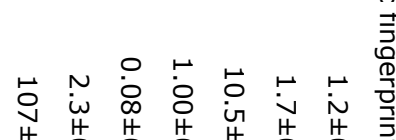

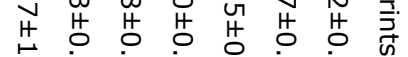

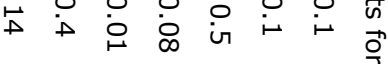

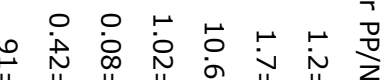

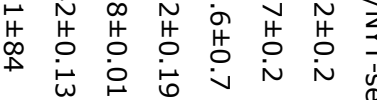

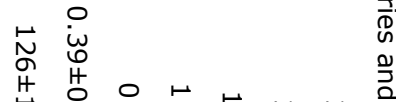

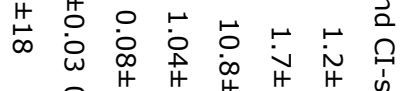

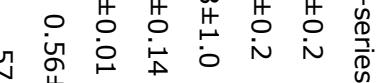

\begin{tabular}{lll}
4 & +1 \\
+ & 0 \\
\hline & 0
\end{tabular}

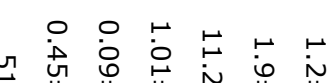

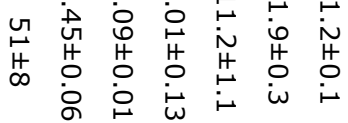

i)

竞

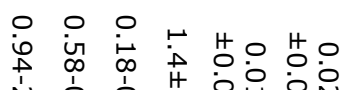

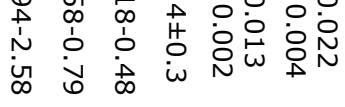

000

定

苟

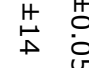

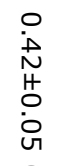

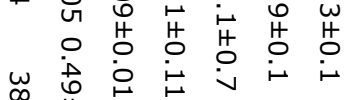

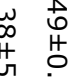

$\dot{5}$

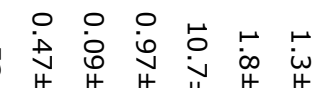

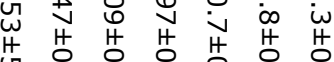

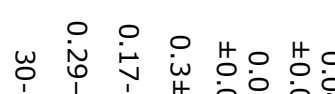

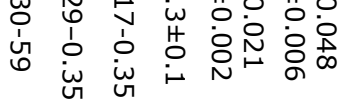

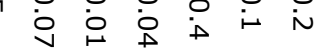

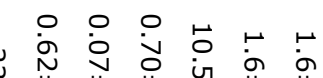

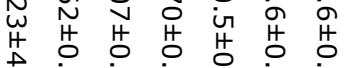

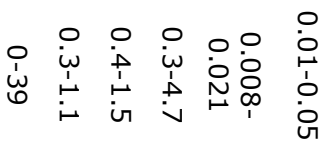

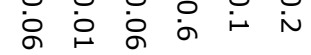

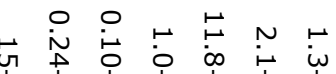

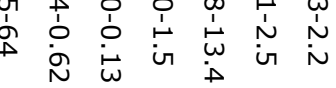

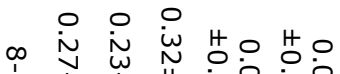

i

峁

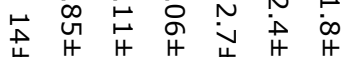

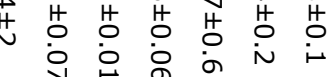

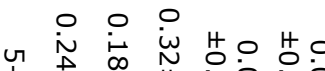

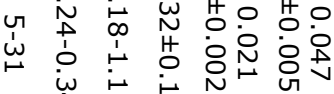

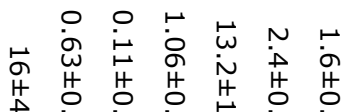

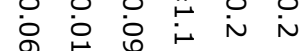

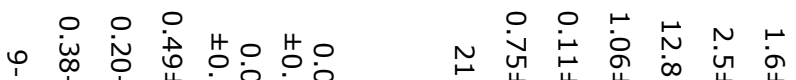

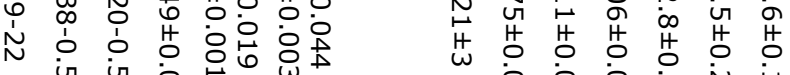

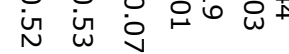

iे $\dot{0}$ iे in $\dot{n}$

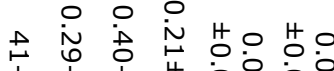

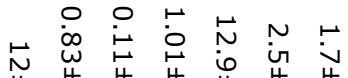

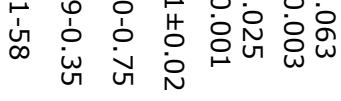

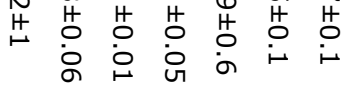

$\circ \circ 0$

$\checkmark$ i

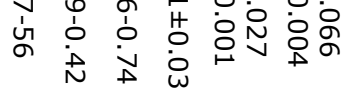

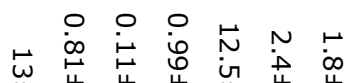

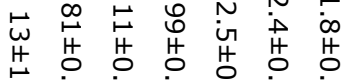

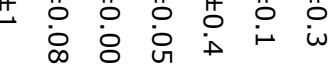

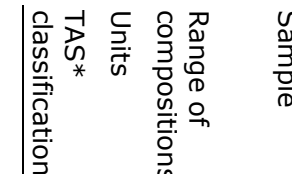

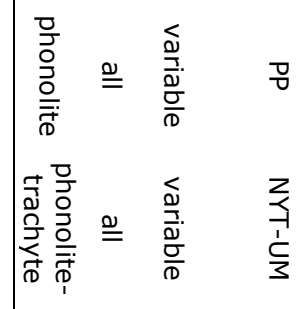

苋产

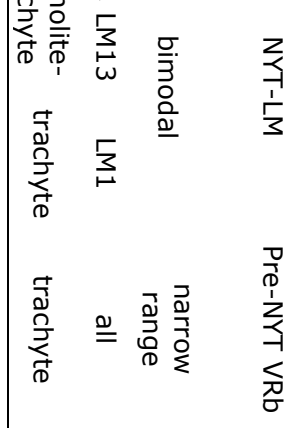

눌 뭉

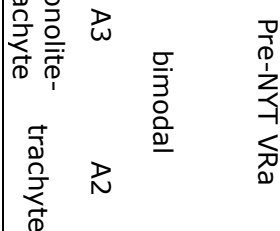

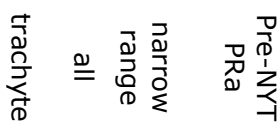

帝

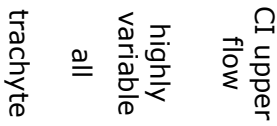

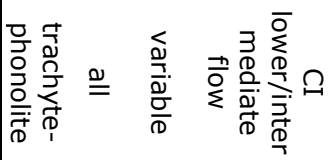

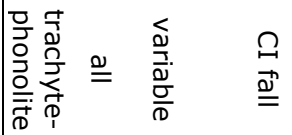

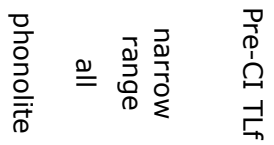

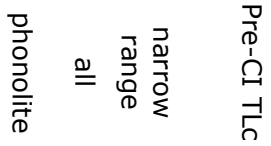

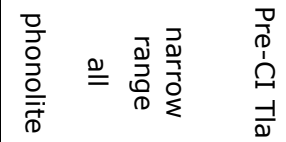




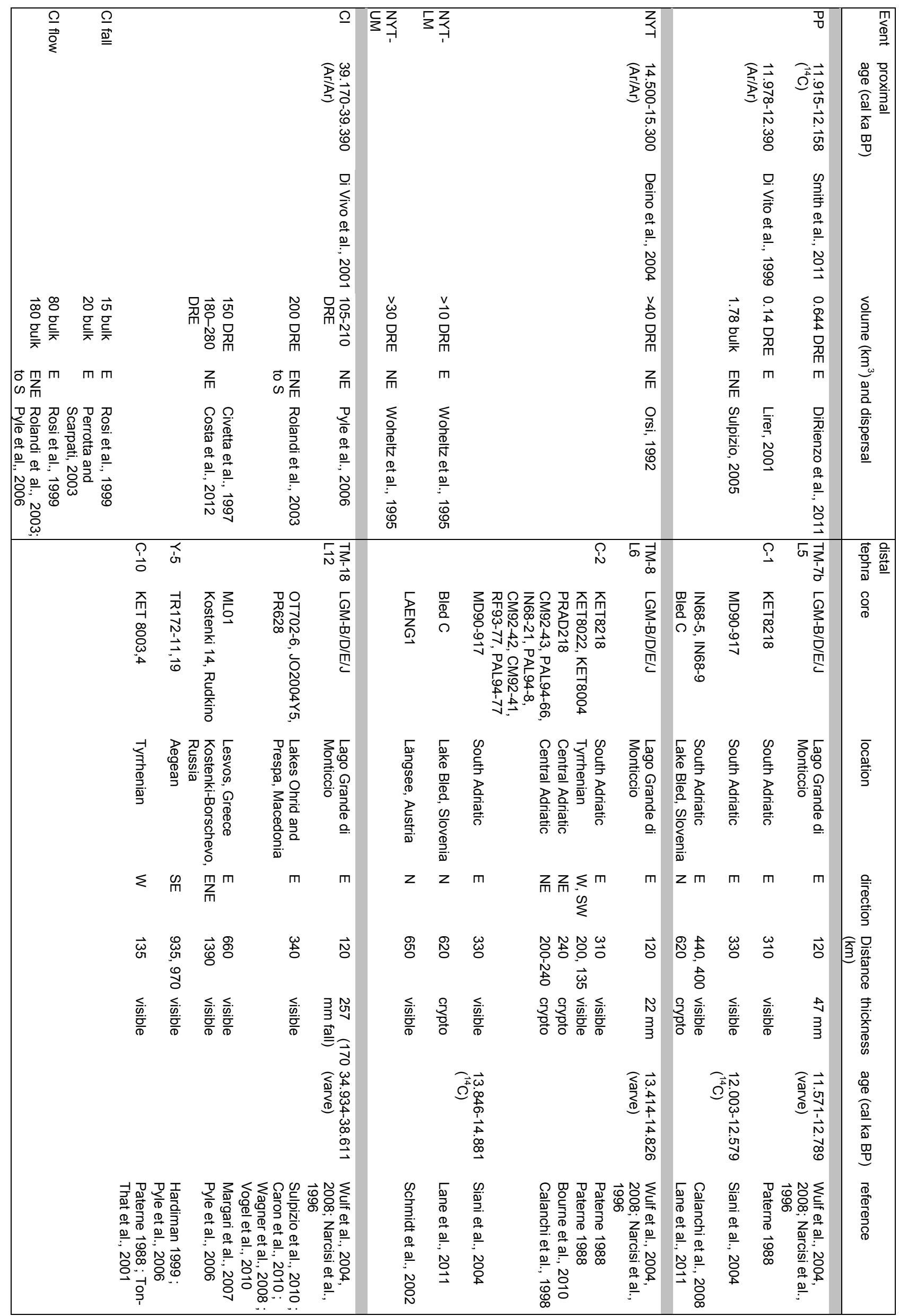




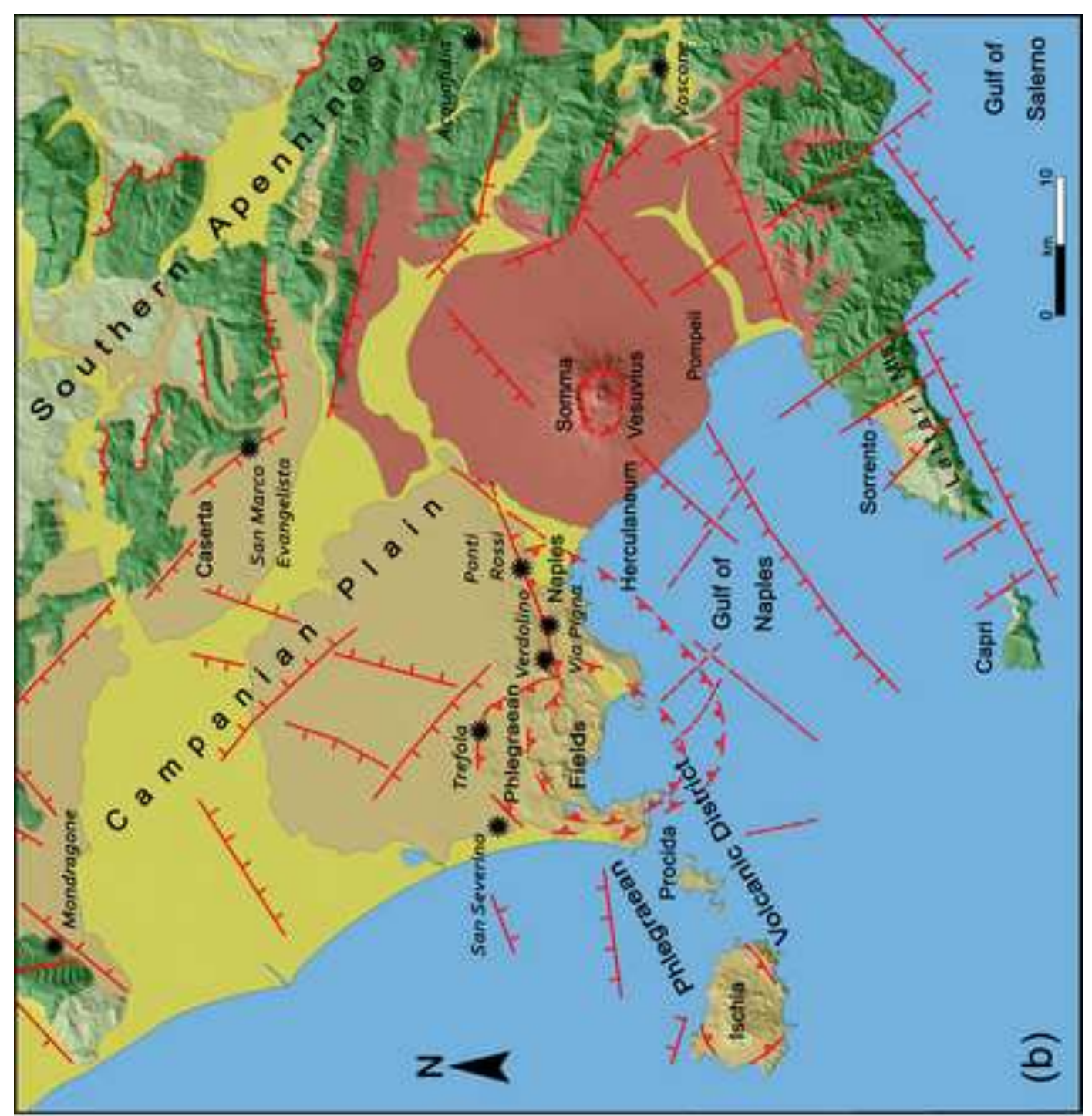

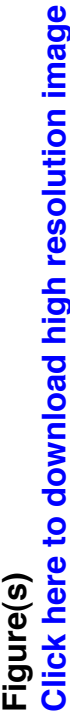

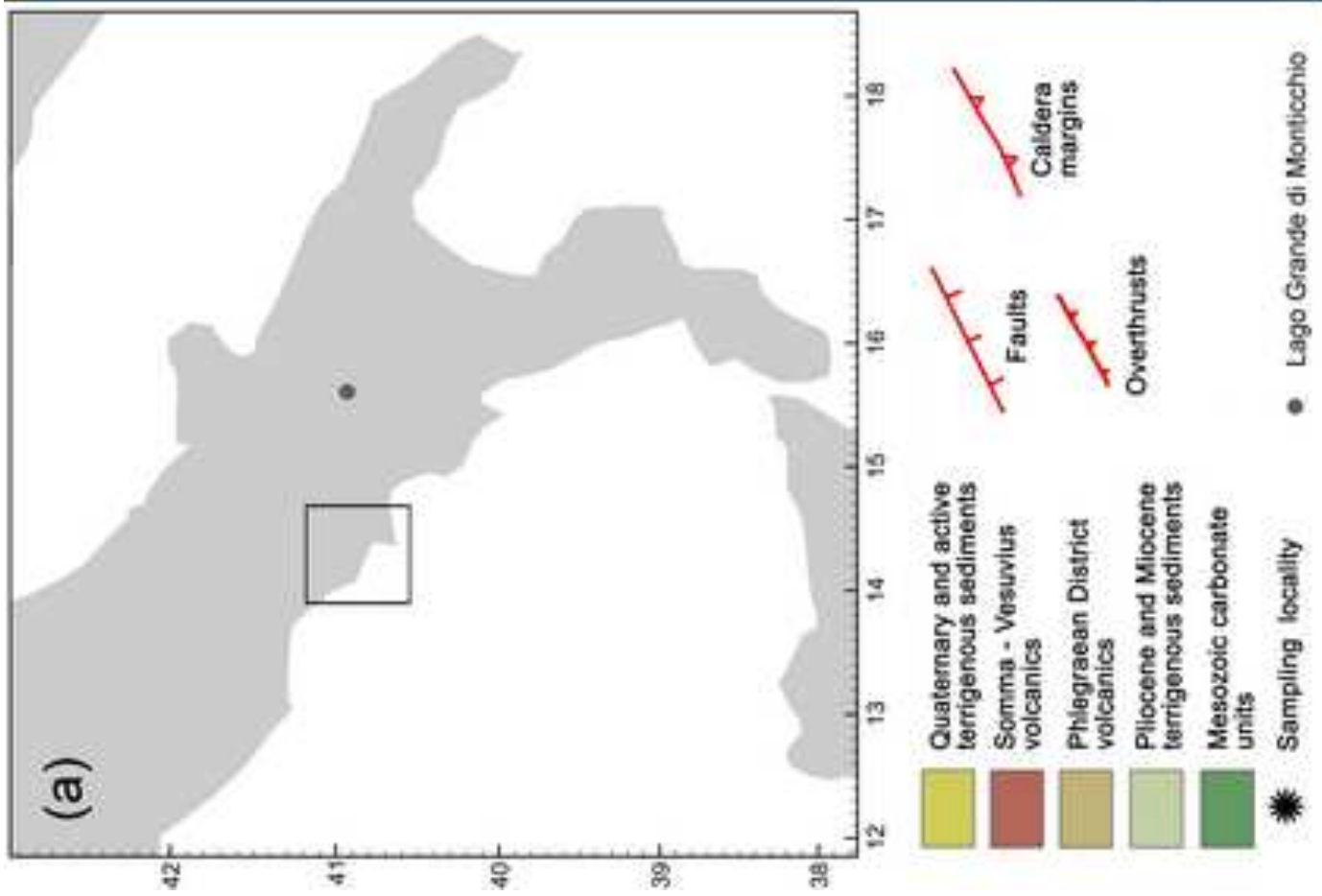




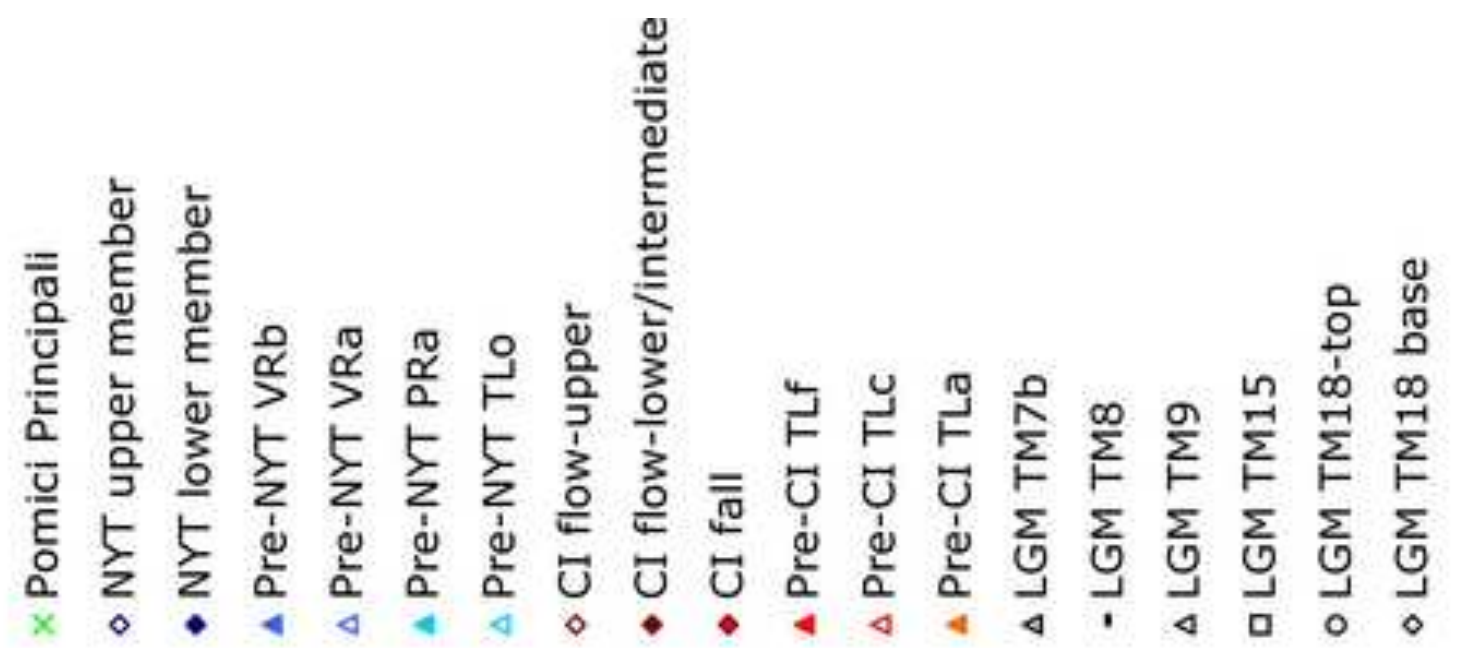

ก
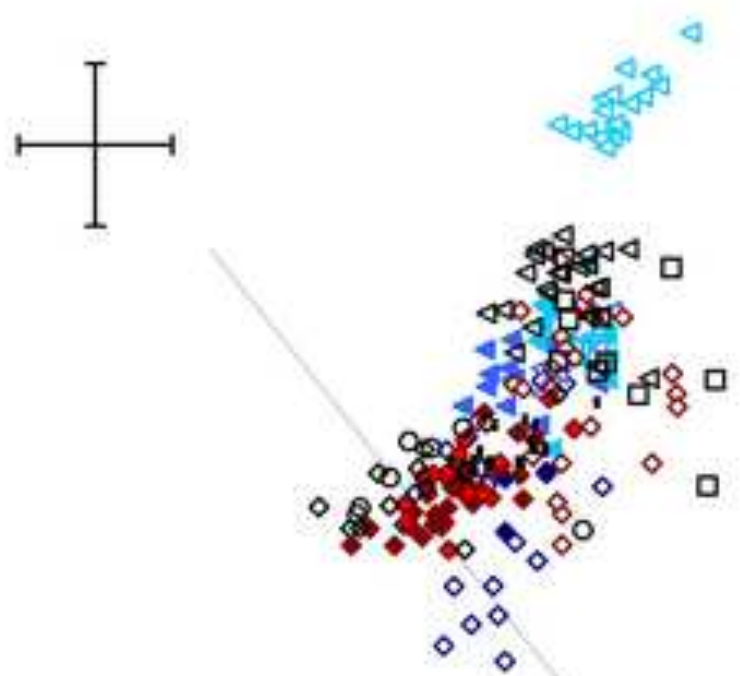

选

m̧

ซै

$\frac{3}{3}$

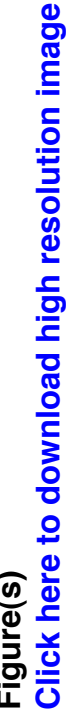

$\frac{0}{\circ}$
$\frac{}{}$
$\frac{1}{}$
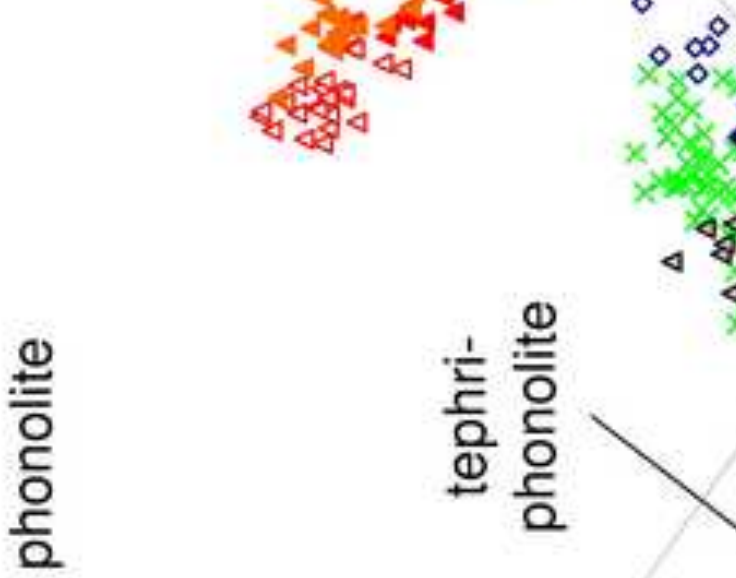

命

อ

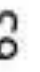
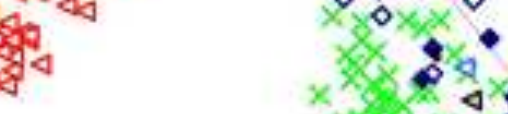

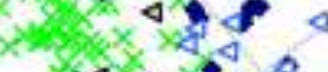

$48 \times 4$

$4 \times 00 \times 0$

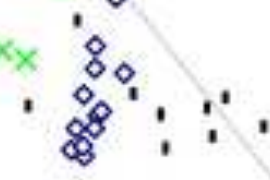

$\frac{\Phi}{\omega}$

는

तั

전

$\stackrel{\bullet}{-1}$

in

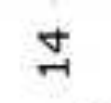

$m$

$\stackrel{-1}{-1}$

กิ

(\%?M) $\mathrm{O}^{z} \mathrm{eN}+\mathrm{O}^{z} \mathrm{H}$ 
Figure(s)

Click here to download high resolution image
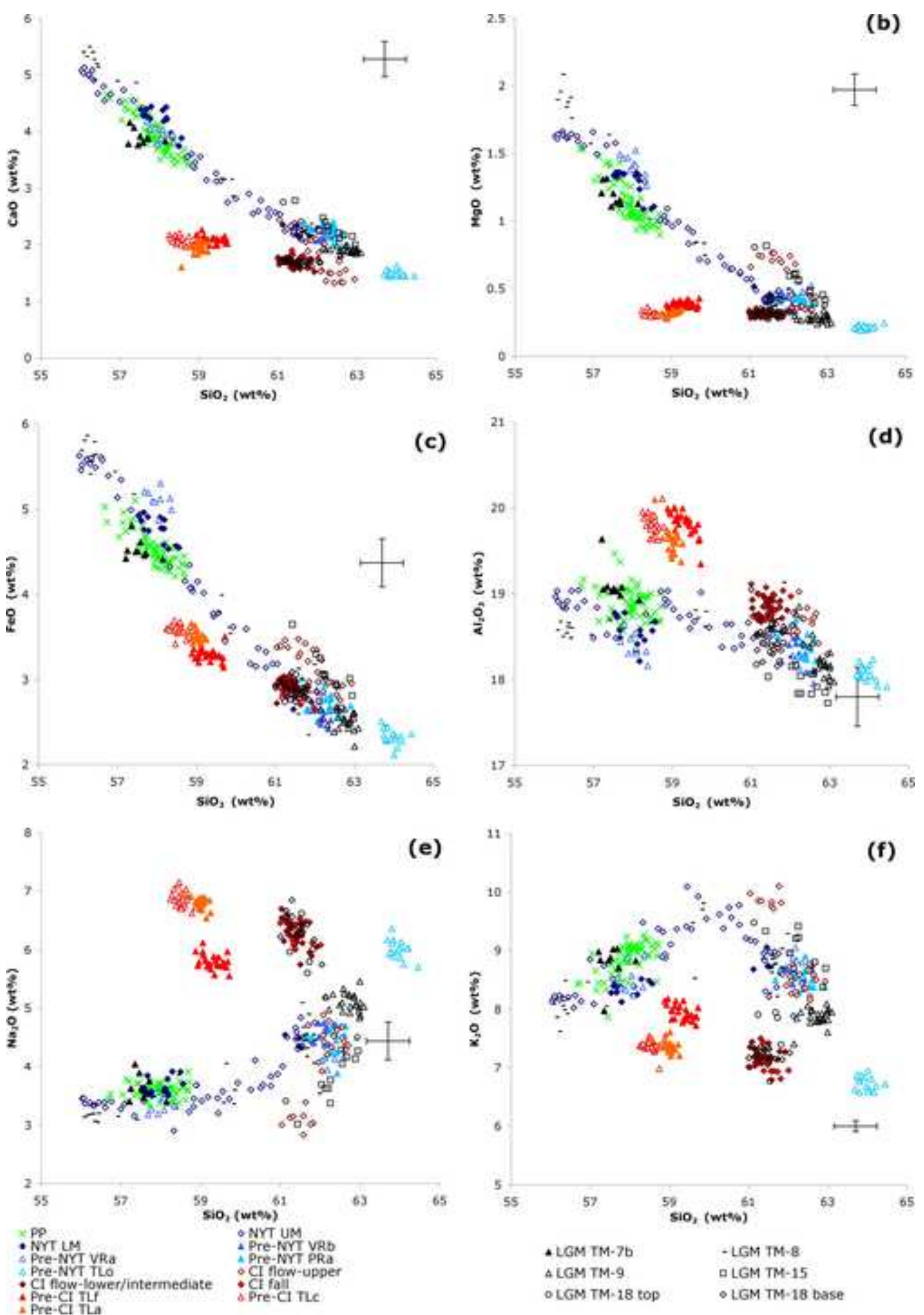

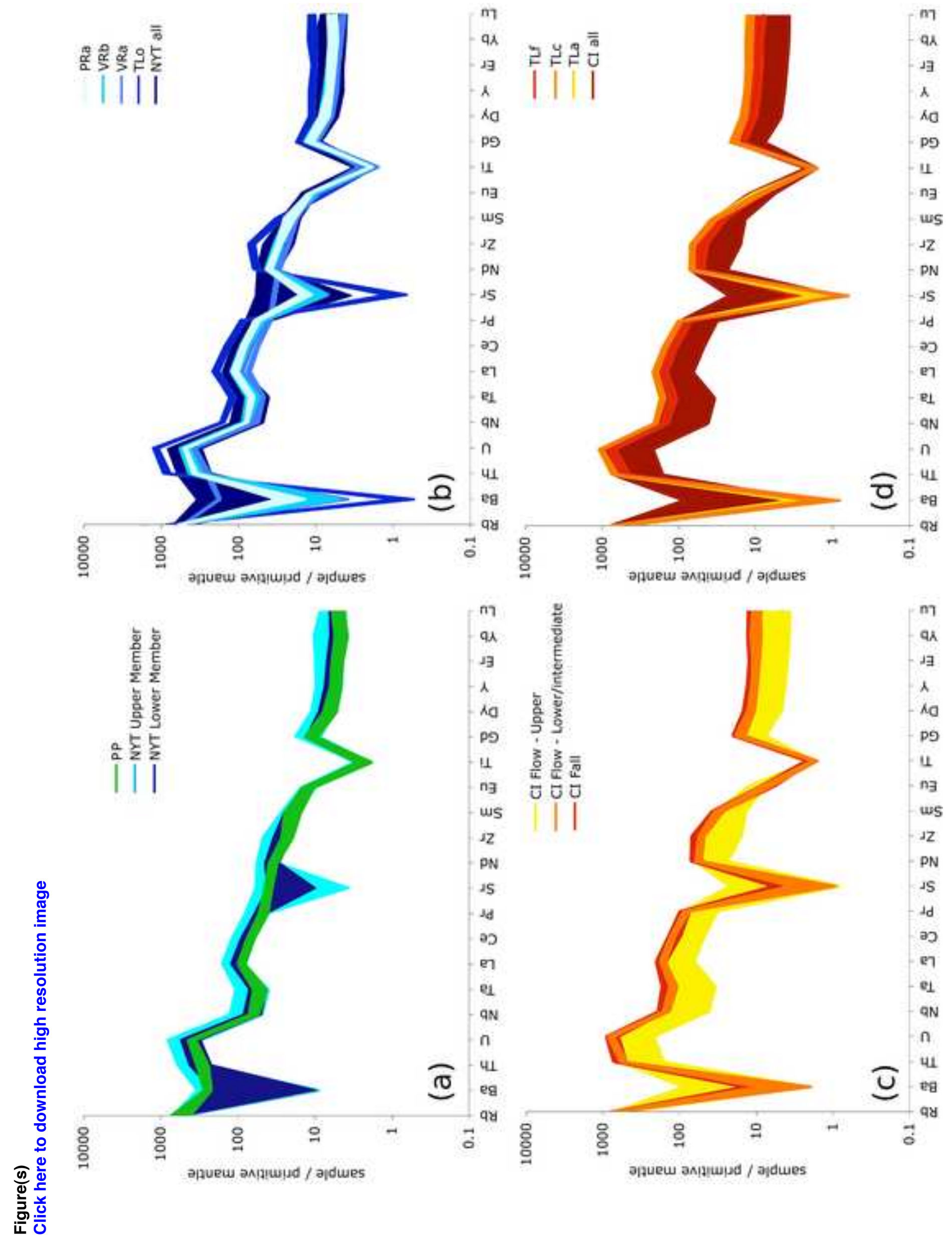


\section{Figure(s)}

Click here to download high resolution image
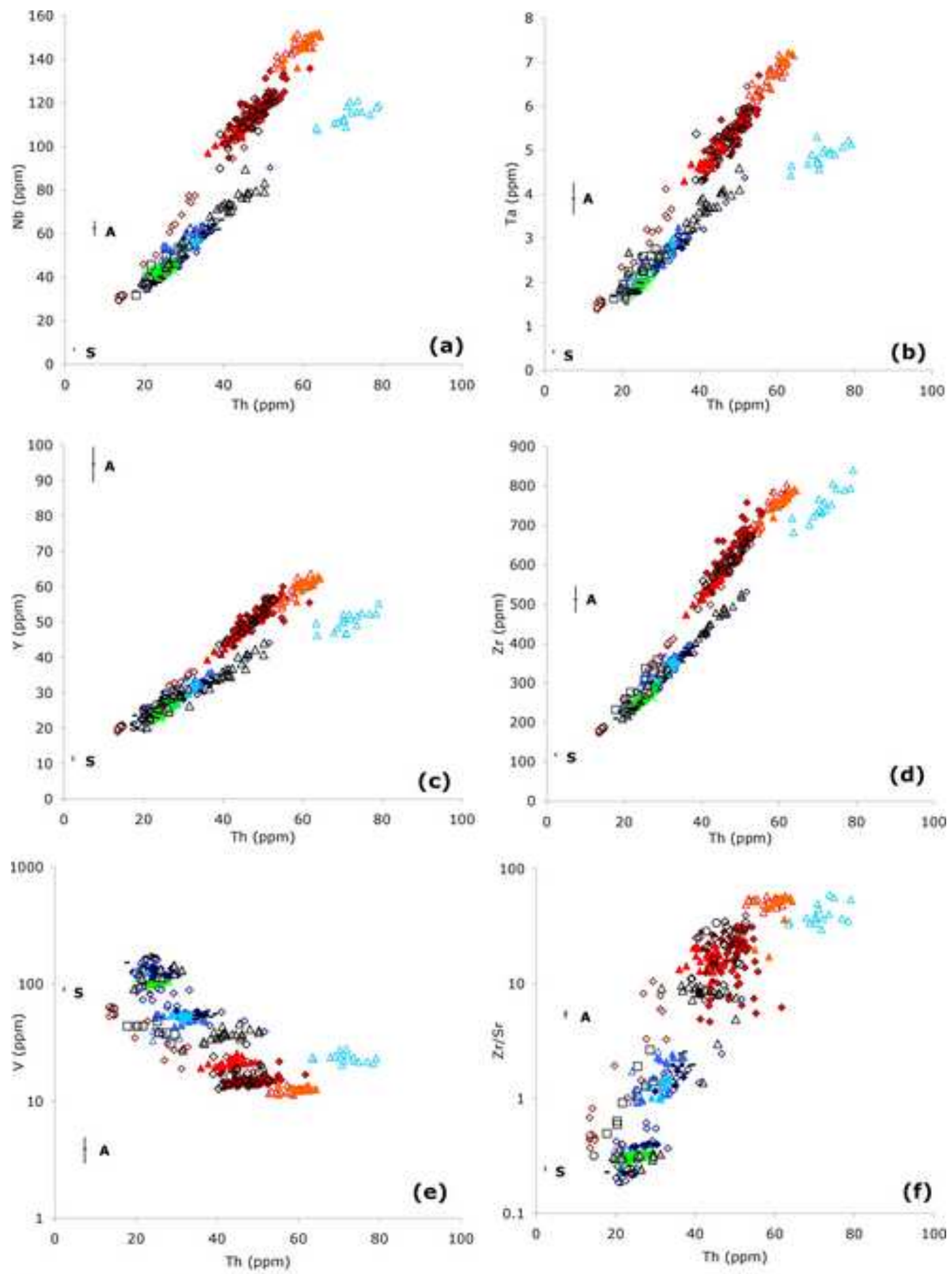

XPP : oNrT upper membes + torT lowes member

a Pre-Nurt vib APre-NrT VRo APre-NorT PRa

ape-NrT TLo $\quad$ OCl - upeer flow $\quad$ Cl fall

- Cr how \& Pre-citur apre-Catte

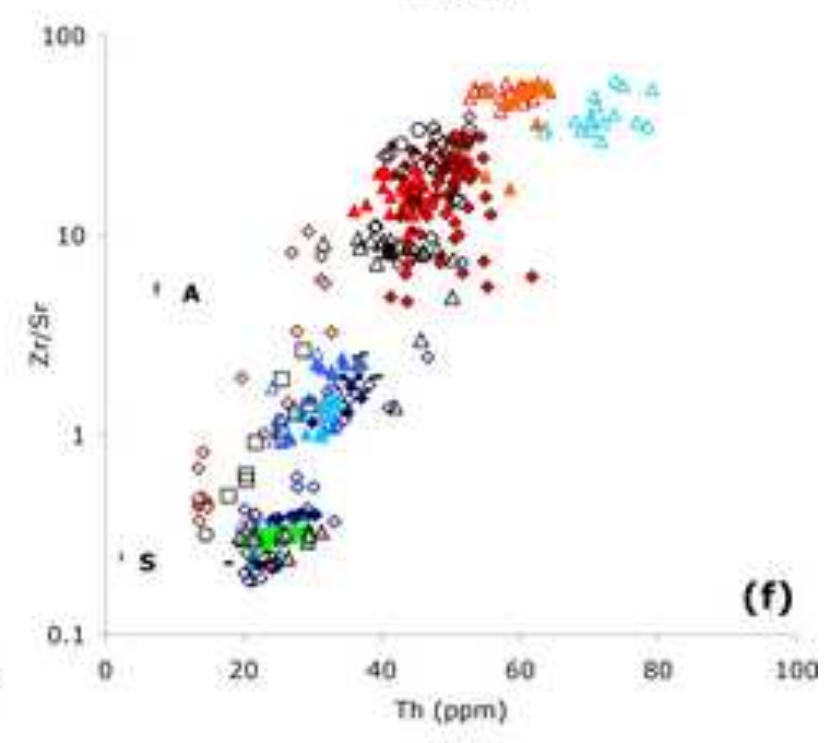

$\triangle L G M T M-7 b \quad-L G M T M-B \quad \Delta L G M T M-9$ DLGM TM-15 OLGMTM-18 top OLGM TM-18 base 


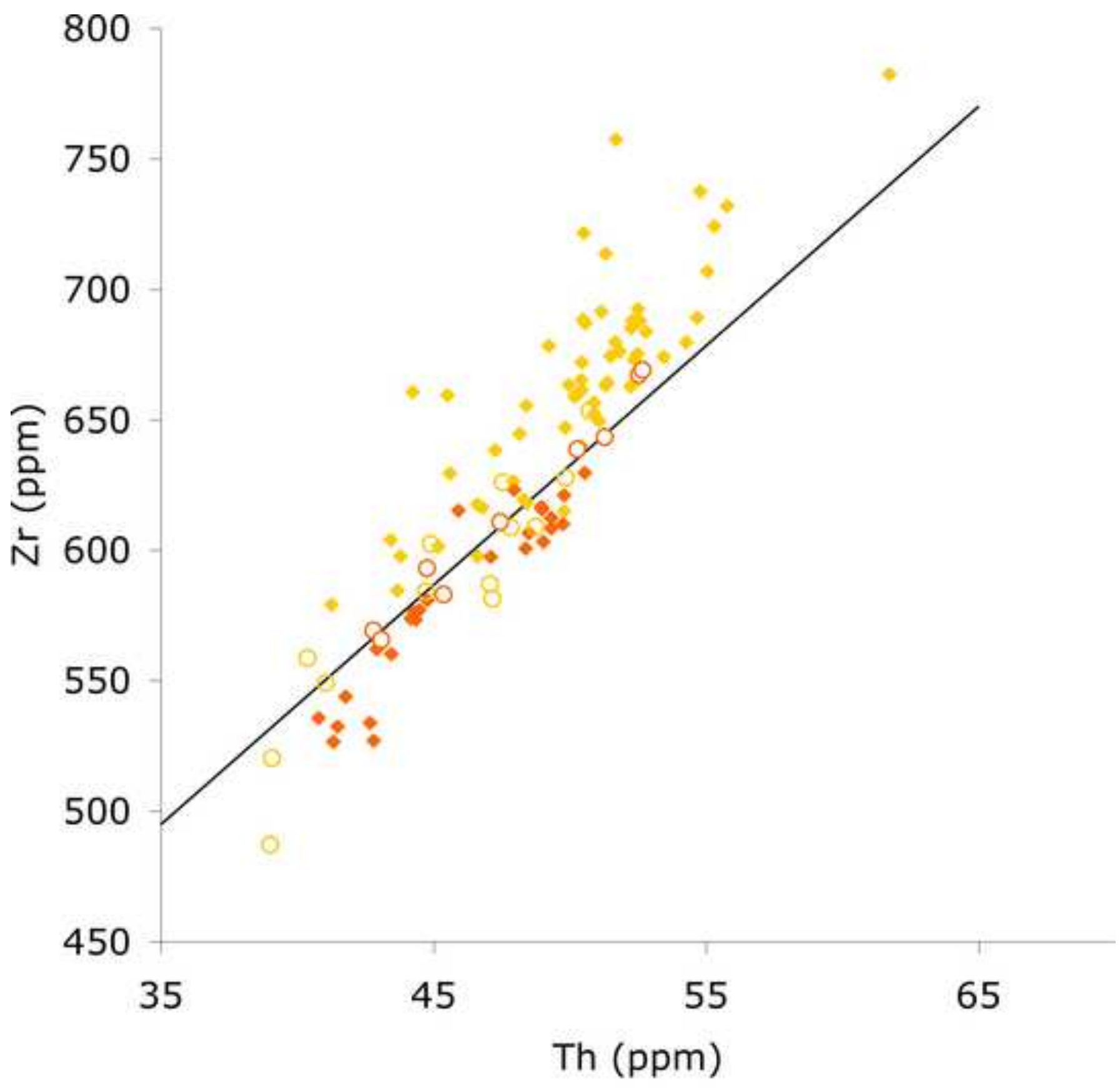

- CI fall - CI flow LGM TM18 base $\circ$ LGM TM18 top 

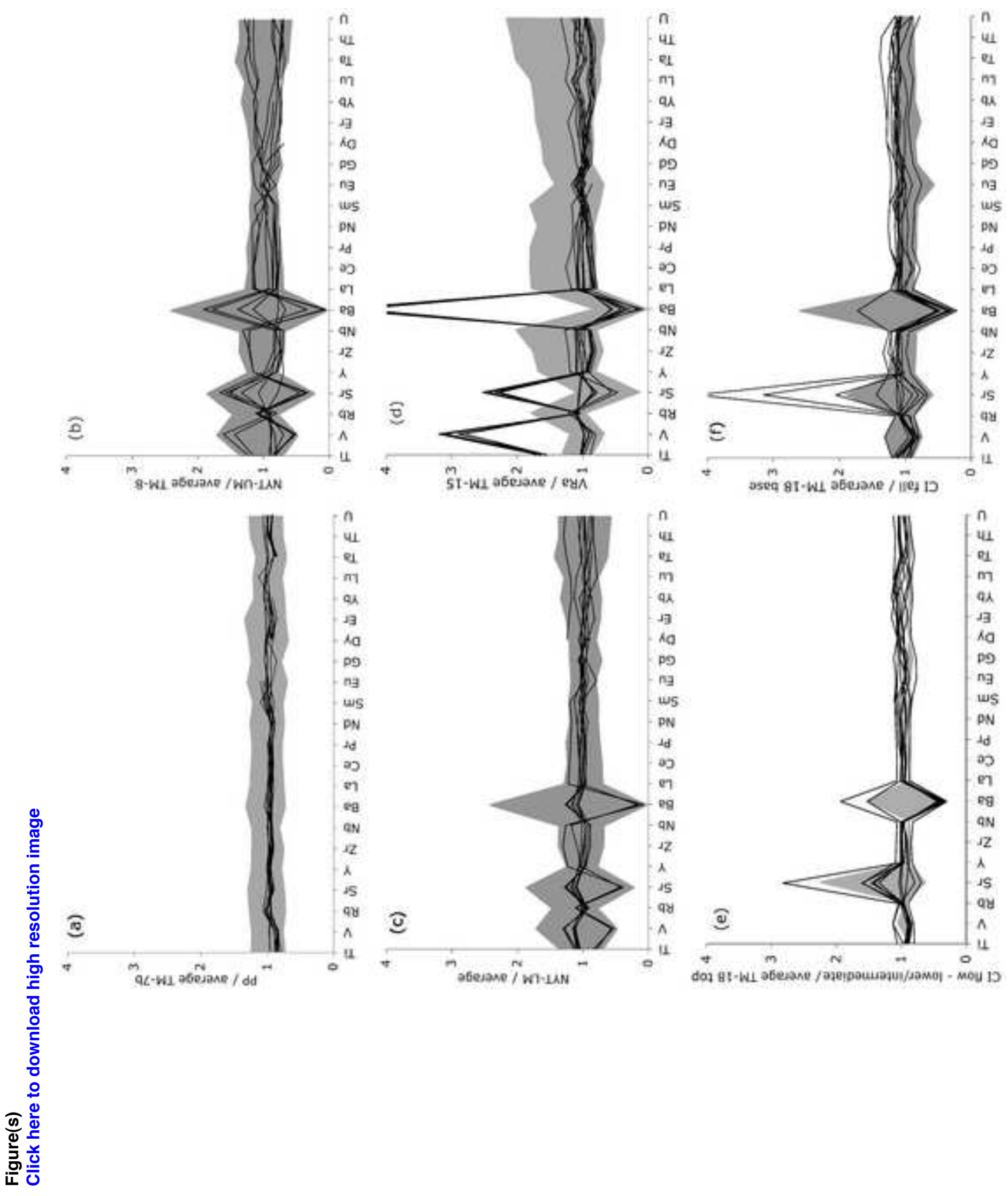

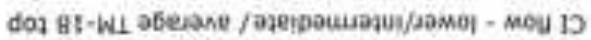




\section{Figure(s)}

Click here to download high resolution image
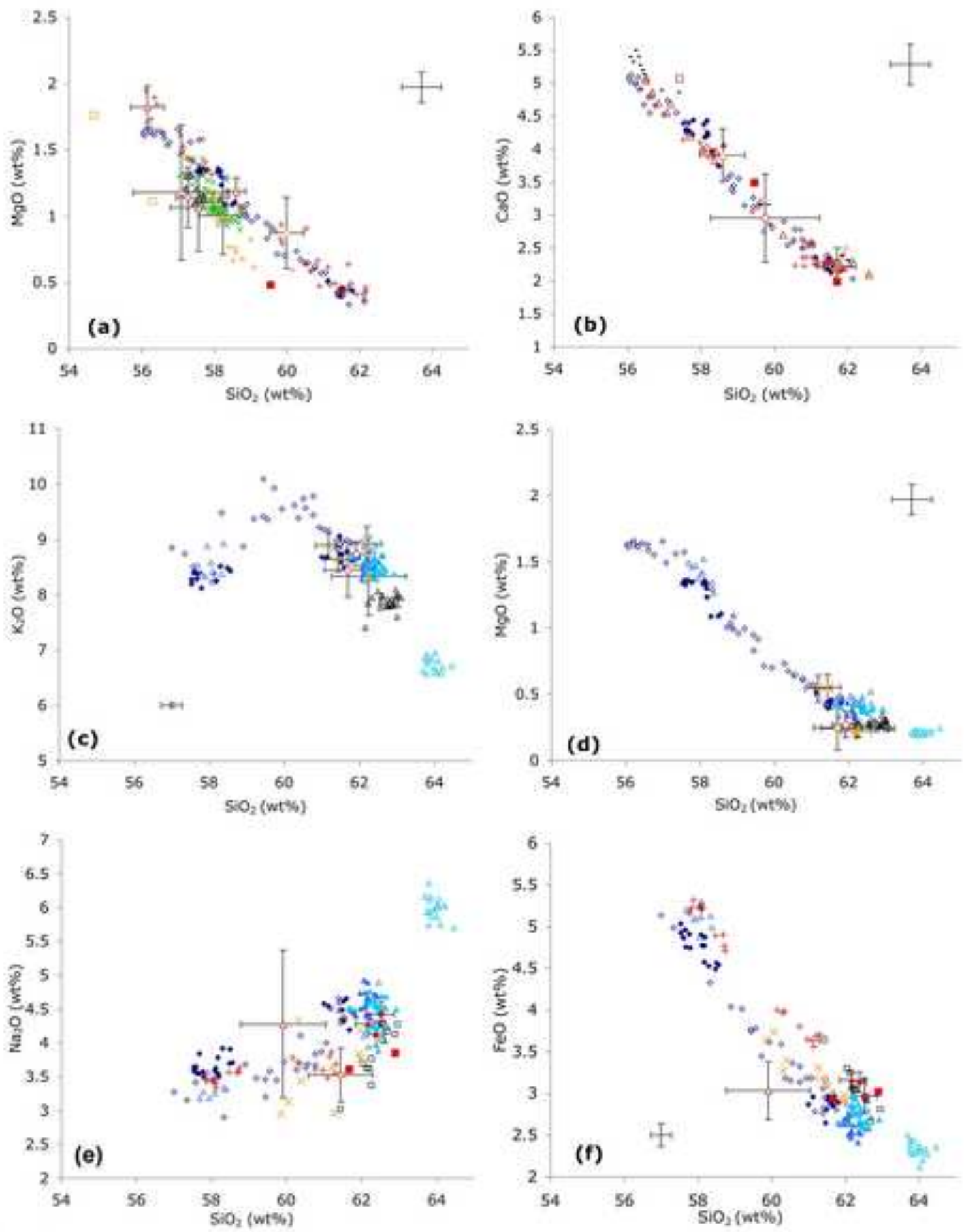

$\begin{array}{ll}\text { *. Pomici Principal } & \text { A LGM TMTb } \\ \text { - NrT upper member } & \text { +LGM TMR } \\ \text { - NYT lower member } & \text { * LGM TM9 } \\ \text { - Pre-NrT VRb } & \text { "LGM TM15 } \\ \text { - Pre-NrT VRa } & \\ \text { - Pre-NYT PRa } & \end{array}$

4 GM1, Somma vesurius (Siani et al., 2004: Andronico et at 1996)

c Lake Ohrid and Prespo, Macedonia (Sulpizio et al., 2010: Caron et al. 2010; Wogner et at., 2008: Vogel et al.,

A Langsee, Austria (Schmidt et al. 2002)

Loke Accesa, Italy (Mangy et al, 2006)

- Lake Bled, Slovenia (Lane et al., 2011)

Lake Shkodra, Aubania and Montenegro (Sulpizio et al, 2010) a Adriatic (Calunchi et al, 1998, 2008)

D Adriatic (Pateme 1988)

- Adriatic (Siani et al. 2004)

- Adriatic (Bourne et al., 2010)

- Tyrrhenian (Munno and Petrosino, 2004)

- Ionian (Keller 1978)

- Tyrrhenian (Paterne 1988) 


\section{Electronic Annex}

Click here to download Electronic Annex: Tomlinson_S1 (version 2).xls 